\title{
4
}

\section{Flow Cytometry Applications in Food Safety Studies}

\author{
Antonello Paparella, Annalisa Serio and Clemencia Chaves López \\ Dipartimento di Scienze degli Alimenti, Università degli Studi di Teramo, \\ Mosciano Stazione TE, \\ Italy
}

\section{Introduction}

Flow cytometry (FC) is a technique for the rapid analysis of multiple parameters of individual cells. One of the limitations of conventional methods for the analysis of cell populations is the determination of a single value for each cell parameter, which is considered representative of the whole cell population. In contrast, FC aims to obtain segregated data, corresponding to different cell subpopulations. In flow cytometers, single cells or particles pass through a light source in a directed fluid stream, and the interaction of the individual cells with the light source can be recorded and analysed, using the principles of light scattering, light excitation and the emission from fluorescent stains. Thus, the data obtained can provide useful information on the distribution of specific characteristics in cell populations.

Although FC has been primarily used for the analysis of mammalian cells, it has indeed important applications in many areas of food microbiology. One of the strengths of FC is the ability to analyse cells rapidly and individually, which can be notably useful to evaluate the distribution of a property or properties in microbial populations, as well as to detect specific microorganisms by conjugating antibodies with fluorochromes. However, the early applications of this technique in food microbiology were hampered by the small size of microbial cells and the difficulty in discriminating the debris. Not only are bacteria one thousandth smaller than mammalian cells, but they also occur in samples that may show a high level of background fluorescence.

These problems can be successfully managed using modern flow cytometers and specific protocols. Developments in fluidics, light sources and optics allow magnifying the optical signals obtained from bacterial cells, while discrimination of different cell components can be achieved using fluorescent labels. In this way, the size range of detectable particles and the possible applications have grown considerably, ranging from zooplankton to single molecules (Cram, 2002). Thus, FC methods are widely used in many areas of microbiology, from protozoology to virology. Whilst the advantages in microbial ecology (Bergquist et al., 2009; Steen, 2000; Wang et al., 2010) and single-cell physiology (Berney et al., 2008; Quirós et al., 2007) are well documented, specific applications in the field of food pathogens can be considered more recent and particularly interesting. 
A flow cytometer consists of five integrated systems: a light source (typically laser or a mercury lamp), optical filters for different wavelength detection, light detectors (photodiodes or photomultiplier tubes) for signal detection and amplification, the flow chamber, and a data processing unit. The sample cells or particles, delivered into a laminar flow, intersect the light source one at a time in the interrogation point. In most flow cytometers, the pneumatic system injects the sample stream into a sheath fluid (hydrodynamic focusing), and light detectors detect the resulting scatter and fluorescence.

Forward scatter is the amount of light that is scattered in the forward direction, which can be considered proportional to the size of the cell. The obscuration bar, placed between the light source and the forward scatter detector, allows detecting the scattering light as each particle passes through the interrogation point; in this way, the forward scatter detector converts intensity into voltage and provides information on the size of the particles.

Side scatter is the light scattered to the side, which is affected by several parameters such as surface structure, particle size and particle morphology (Mourant et al., 1998). Side scatter is focused through a lens system and is collected by the side scatter detector, which is usually placed at 90 degrees from light source direction.

Specific cell components can be selectively determined by measuring the intrinsic fluorescence of some compounds or staining the cells with fluorescent dyes. Fluorescence signals travel along the same path as side scatter, being directed through different filters and mirrors to reach a series of detectors for different wavelength ranges.

Fluorescent labelling is commonly used to discriminate different microbial cell types in FC assays. Generic dyes can be utilized to detect cell components or particular biological activities, as well as to discriminate cells from debris. In addition, staining protocols have been developed for specific applications in food microbiology. For example, different fluorogenic substrates can be selected to label microbial cells according to expression of specific enzyme activities; the application of many fluorescent dyes for microbiological analyses has been reviewed by Davey \& Kell (1996), Attfield et al. (1999), Veal et al. (2000), Comas-Riu \& Rius (2009), and Sträuber \& Müller (2010). In particular, the use of esterified fluorochromes is now a routine procedure in food microbiology, to gain information on viability and vitality of cells (Breeuwer et al., 1994). These fluorochromes become fluorescent only after cleaving by intracellular enzymes, and this leads to cell fluorescence if intact membranes retain the fluorescent product. Therefore, these methods provide important information on different cellular functions such as esterase activity and membrane integrity.

On the other hand, Fluorescence In Situ Hybridization (FISH) methods discriminate specific nucleic acid sequences inside intact cells (Delong et al, 1989), thus labelling cells according to phylogeny (phylogenetic labelling); a combination of CARD-FISH (Catalyzed Reporter Deposition) and FC has recently been proposed for bacterial cell quantification within natural microbial communities. Finally, fluorescent antibodies can label microorganisms according to expression of selected antigens (immunological labelling), even when high levels of contaminating molecules are present (Veal et al., 2000).

Fluorescence and scatter data, amplified by photomultipliers, are processed by the data processing unit, and the results are combined in different ways to highlight discrimination of subpopulations. In most cases, two-dimensional dot plots and two-colour dot plots are 
used to represent cytometric data, e.g. combining forward scatter and side scatter, or two different dyes (Nebe-von-Caron et al., 2000); moreover, the data can be processed by multiparameter analysis and suitable graphic methods can be used to improve extraction of information (Davey et al., 1999).

Some specialized flow cytometers are equipped with Fluorescence-Activated Cell Sorting or FACS (Battye et al., 2000). This technology allows separating specific cell subpopulations for further analyses such as proteomics or downstream genomics. Most sorters use a droplet formation device, which breaks the sample stream into droplets by means of a vibrating piezoelectric crystal inside the flow chamber. Droplets containing segregated cells pass through a high-voltage electrical field and are collected into different vessels. Droplet cell sorters can sort thousands of cells per second, while simple sorters have a capacity of hundreds of cells per second.

The applications of FC and cell sorting in food safety studies include the study of viable but not culturable cells (VNC), the recovery of rare mutants, and the isolation of slow-growing pathogens from mixed microbial communities (Katsuragi \& Tani, 2000).

This chapter reviews the applications of FC in food safety studies, with particular emphasis on foodborne pathogens. Compared to other reviews (Alvarez-Barrientos et al., 2000; Bergquist et al., 2009; Davey \& Kell, 1996; Vives-Rego at al., 2000), we analyse the recent developments of FC in the field of foodborne pathogens and point out the possible perspectives in food safety studies.

\section{Cellular measurements in food microbiology}

\subsection{Physiological state of microorganisms}

The physiological state of microorganisms influences their ability to survive and grow in foods. In recent years, remarkable progress has been made in the design of rapid methods for determining viability and growth of microbial living cells. In fact, the rapid and specific detection of microorganisms is a challenge in food safety studies, particularly in presence of complex indigenous communities or subpopulations varying in viability, activity and physiological state (Hammes \& Egli, 2010). On the other hand, measurements of microbial growth are useful to test antimicrobial substances, as well as to evaluate the efficacy of sanitization and food processing methods, in order to provide information in making decisions on the microbiological safety of foods.

Although viability and culturability are key concepts in food microbiology, the use of these words in scientific literature has often been confusing. The following definitions have been proposed by Paparella et al. (2008):

- viable cells, able to reproduce themselves, having both metabolic activity and membrane integrity;

- $\quad$ vital cells, which are living cells that do not necessarily show their reproductive activity on growth media;

- viable but not culturable cells, which are metabolically active, but do not form colonies on non-selective growth media and can remain in this state for more than a year;

- sublethally stressed cells, which do not show any viability loss, but reduce or arrest their growth rate; 
- injured cells, whose growth is impaired due to damage to cellular components;

- inactivated cells (dead cells), which are not able to resume growth when they are inoculated into media that would normally support their growth.

FC is used in food microbiology to provide real time counting of microorganisms, to gather information on the physiological state of individual cells and heterogeneous microbial populations, to detect and identify specific microorganisms, and to sort cells for further analyses. These measurements can be performed using fluorescent dyes aimed at specific cellular targets such as DNA, enzyme activities, internal $\mathrm{pH}$, or cytoplasmic membrane. Fluorescent or fluorogenic dyes are frequently used as indicators for the following cellular functions: (a) membrane integrity; (b) bacterial respiration; (c) membrane potential or (d) intracellular enzyme activity.

\subsection{Membrane integrity}

Microbial viability can be monitored by FC using the cell capacity to maintain an effective barrier to external media. This approach promotes a better understanding of cellular injury sites and compromised metabolic activities, based on the real time assessment of the viability of the single cells. In a healthy cell, the cytoplasmic membrane allows selective communication with its immediate environment by means of passive and active transport systems. Cells with a damaged membrane cannot sustain any electrochemical gradient and are normally classified as dead cells.

FC can be used to estimate cell membrane integrity, by staining cells with fluorescent dyes that can cross intact cytoplasmic membranes. Therefore, dyes that are normally cell impermeable and have specific intracellular binding sites, can be used to measure membrane integrity. In particular, membrane integrity can be detected by dye exclusion or dye retention. For example, propidium iodide (PI) or ethidium bromide (EB) are exclusion dyes; being positively charged, they bind nucleic acids but cannot cross an intact cytoplasmic membrane. Following the loss of membrane integrity, PI diffuses and intercalates into DNA or RNA, staining cells with a red fluorescence emission. Different dyes, like the cell-impermeant SYTOX® family, have been used to detect nucleic acids in bacteria having a lower DNA content. Moreover, 7-aminoactinomycin D (7-AAD) is a useful alternative to PI, which can penetrate only into dead cells with compromised membrane integrity; this dye is preferable as a viability marker when fluorescein isothiocyanate (FITC) and phyco-erythrin (PE) are used to label surface antigens (Schmid et al., 1992).

\subsection{Membrane potential}

Membrane potential $(\Delta \Psi)$ is considered an early indicator of cell damage. In fact, an electrical potential difference drives and regulates secondary ion and solute transfer across the membrane. Membrane potential, together with the $\mathrm{pH}$ difference between the inside and the outside of the cell $(\Delta \mathrm{pH})$, constitutes the proton motive force (Michels \& Bakker, 1985; Richard \& Foster, 2004). As cell wall damage and cell death cause membrane depolarization, $\Delta \Psi$ reflects both the physical integrity of cytoplasmic membranes (viability indicator) and the activity of energetic metabolism (physiological indicator). $\Delta \Psi$ can be detected with membrane potential sensitive dyes such as the anionic lipophilic dye bis-(1,3dibutylbarbituric acid) trimethine oxonol, named $\operatorname{DiBAC}_{4}(3)$. This dye has only a low 
binding affinity for intact membranes and is limited to the outer regions of the cell membrane in living bacteria. Therefore, $\operatorname{DiBAC}_{4}(3)$ is excluded by live polarized cells, because they are negatively charged in the interior, while it enters into depolarized cells and binds to lipid rich surfaces resulting in bright green fluorescence. In Gram-negative bacteria, a possible problem for measurement of the membrane potential, is that the proper distribution of the membrane potential probes is sometimes hindered by the low permeability of the outer membrane (Breeuwer \& Abee, 2004). Although the addition of EDTA or EGTA can favour permeabilization of the outer membrane, such treatments may obviously influence cell viability. Finally, rhodamine 123, a cationic lipophilic dye that partitions into the low electrochemical potential of mitochondrial membranes, can be used to evaluate the functional status of mitochondria in eukaryotic cells.

\subsection{Intracellular enzyme activities}

Intracellular enzyme activities, and in particular esterase and dehydrogenase activity, provide important information on the metabolic state of microbial cells. A number of esterase substrates have been evaluated on several organisms. The measure of esterase activity can be assessed by dye retention methods that use non-fluorescent cell-permeant esterase substrates as fluorescein diacetate (FDA), carboxyfluorescein diacetate (CFDA), or chemChrome B (Joux \& Lebaron, 2000). cFDA is a lipophilic, non-fluorescent precursor that readily diffuses across the cell membranes; once inside the cell, it is converted by nonspecific esterases to a membrane-impermeant fluorescent compound, carboxyfluorescein (cF), resulting in fluorescein accumulation over time. Retention of the dye by the cell, by its electrical charge and polarity, indicates membrane integrity and functional cytoplasmic enzymes, while dead cells do not stain because they lack enzyme activity, and therefore $\mathrm{cF}$ diffuses freely through the damaged membranes.

Moreover, the reduction of tetrazolium salts has been widely used as a measure of dehydrogenase activity and cell viability. Tetrazolium salts act as artificial acceptors of electrons and therefore have become an indicator also referred to as the activity of the electron transport system (Lew et al., 2010). In particular, 5-cyano-2,3-ditolyl tetrazolium chloride (CTC) is reduced by electron transfer from the respiratory chain with formation of a water-insoluble red fluorescent intracellular formazan. The reduction of CTC in a cell is considered as an indicator of microbial respiratory activity in environment (Rezaeinejad \& Ivanov, 2011).

\subsection{Intracellular pH}

Intracellular $\mathrm{pH}$ affects a wide range of cellular processes and functions such as control of DNA synthesis, cellular proliferation, protein synthesis rate and glycolyis/gluconeogenesis, by governing the uptake of nutrients. As a result, it is regulated within a narrow range by a variety of transport proteins that transfer ions across the cellular membrane. It is believed that viable cells need to maintain a transmembrane $\mathrm{pH}$ gradient with their intracellular $\mathrm{pH}$ above the acidic extracellular $\mathrm{pH}$; failure to maintain intracellular $\mathrm{pH}$ homeostasis indicates that the bacterial cell is severely stressed, and ultimately leads to a loss of cell viability (Kastbjerg et al., 2009). Thus, intracellular $\mathrm{pH}$ can also be used as an indicator of the physiological state and metabolic activity of cultivated cells, and as a measure of viability. The fluorescent dyes used for intracellular $\mathrm{pH}$ measurements should be non-toxic and 
should have a $\mathrm{p} K_{\mathrm{a}}$ within the physiological range (6.8 and 7.4), to allow detection of small $\mathrm{pH}$ changes; clearly, they should have excitation and emission wavelengths suitable for detection by FC. In particular, a variety of fluorogenic esterase substrates like 2',7'-biscarboxyethyl-5,6-carboxyluorescein (BCECF-AM), calcein-AM, and various fluorescein diacetate derivatives are available for measurement of intracellular $\mathrm{pH}$.

\section{Application of flow cytometry to viability assessment and cell counting}

\subsection{Plate count and rapid methods}

Stress responses are of particular importance to food pathogens, as they are commonly exposed to a number of stressors during processing such as heating, freezing, $\mathrm{pH}$ changes, high osmotic pressure, oxidative stress, chemical preservatives and biopreservatives. Many studies have highlighted the substantial impact of microbial stress on cell growth probability and showed that the proportion of growing cells is dependent on the stress encountered (Dupont \& Augustin, 2009; Vermeulen et al., 2007). The ability to distinguish among different physiological states is especially important in assessing survival and growth of pathogenic microorganisms. Furthermore, accurate measurement of biomass concentration is necessary if informed decisions on process control are to be made, because process performance will largely depend on cell number and individual cell physiological states (Hewitt \& Nebe-Von-Caron, 2001).

Microbiological analysis of foods is normally performed by colony counting on agar plates. In plate count method, the time needed for the formation of visible colonies is relatively long, from 20-24 hours for the fast-growing organisms to a week for some slow-growing bacteria. In addition, this method lacks in sensitivity, in particular in traditional fermented foods, and it reveals only a part of the population, as a number of novel microorganisms are not culturable in common media. Moreover, this method is heavily dependent on the physiological status of microorganisms. In fact, bacteria may exist in an eclipsed state, defined as viable but not culturable; in VNC condition, cells are metabolically active, do not form colonies on non-selective growth media and can remain in this state for more than a year (Roszak \& Colwell, 1984). The VNC state is only one of the possible microbial responses to stress conditions. Indeed, microorganisms may also become sublethally stressed cells when they are exposed to detrimental nutritional conditions, toxic chemicals and sub-optimal physical conditions (Neidhardt \& VanBogelen, 2000), which adversely affect growth without impairing survival.

Despite these limitations, plate count method remains the gold standard in food microbiology. Several rapid methods have been developed for the microbiological analysis of foods, based on direct microscopic examination, optical density, dry-cell-weight or capacitance. However, many of these techniques show significant limitations that hamper their potential application in food safety studies. For example, optical density and dry-cellweight cannot assess cell viability and are unable to distinguish different cell types. Capacitance methods rely on the measurement of the capacitance generated in an intact cell when passing through an electrical field; although there is a good linear correlation between optical density and capacitance for high biomass concentrations, problems occur when biomass concentrations are low or the ionic strength of the medium is high (Hewitt \& NebeVon-Caron, 2001). Moreover, capacitance does not provide information on the physiological state of the cells after chemical or physical stresses. 
To estimate microbial population density and viability, fluorescence microscopy has been successfully used. In this method, microorganisms are stained with acridine dyes to differentially label viable and non-viable cells, which are enumerated using fluorescence microscopy. In particular, Direct Epifluorescent Filter Technique (DEFT) has been used for many years for direct quantification of microbial load in a variety of applications. The major advantages of this technique are: the very short time required for determination of microbial numbers and the elimination of overnight incubation. Active and non active cells can be distinguished by the different reaction of the dye with nucleic acids, with viable microorganisms resulting in an orange and orange-yellow fluorescence under illumination with blue light at 450-490 nm, related with the high RNA content present in the active cells (Kroll, 1995). Conversely, nonviable microorganisms show green fluorescence and are not counted, since this fluorescence is correlated to the presence of DNA.

Although DEFT it is a relatively rapid and sensitive method, acridine dyes react indiscriminately with organic material, and interference from preservatives such as sorbic acid has been reported; moreover, foods with high fat content are not suitable for DEFT analysis (Kroll, 1995). These substances which often interfere with the outcome of the microbiological analysis, are also considered an important reason for requiring enrichment and isolation steps before the use of highly specific assays such as ELISA methods and PCR (Tortorello \& Stewart, 1994).

\subsection{Flow cytometric assessment of microbial viability and cell number}

To overcome the limitations and drawbacks of the rapid methods, FC in combination with selected fluorescent probes has been adapted for cell counting and for the analysis of the viability, metabolic state and antigenic markers of food microorganisms (Barker et al., 1997; Boulos et al., 1999; Bolter et al., 2002; Buyanovsky et al., 1982; Comas-Riu \& Rius, 2009; Davey \& Kell, 1996;). FC measurements are made very rapidly on a large number of individual cells and give objective and accurate results. In fact, using fluorescent dyes with defined cellular targets along with suitable staining strategies, it is possible to separately examine specific cellular metabolic activities and their relative changes after food processing treatments. Compared with direct microscopic examination, FC is more than four times faster (3-5 min per sample compared to $>20$ min per sample) and more accurate $(<5 \%$ standard deviation compared to $>10 \%$ ) (Wang et al., 2010).

In FC, discrimination of different cell types and cell counting are mostly performed using fluorescent labelling. The choice of the fluorescent dye, aimed to stain biologic material or respond to biological activities, is of paramount importance to achieve a reliable assessment of microbial viability (Berney, et al. 2006; Freese, et al. 2006; Nebe-von-Caron, et al. 2000). Viable cells are normally labelled with cationic dyes, whilst lipophilic anionic dyes stain non-viable cells. In multi-colour fluorescence FC, two fluorescent probes are combined to obtain simultaneous detection of viable and non-viable microorganisms, e.g. PI and cFDA, or the permeant SYTO 9 (green) and the non-permeant PI.

Discrimination between intact and permeable cells by FC and fluorescent stains has been used in many studies on bacteria and yeasts in synthetic media, as well as in real systems. This approach has provided additional insights into the subtle changes of cellular events induced by food processing, which were not explicitly assessable by culture techniques. 
Evidence of the advantages of FC is given by the advances achieved in particular areas of food microbiology such as the research on lactic acid bacteria, where this method was proved to be a powerful and sensitive tool for assessment of the cell viability and stability (Ben Amor et al., 2002; Bunthof et al, 2001). In particular, multiparametric FC, using multiple stains, was used successfully to differentiate lactic acid bacteria according to their susceptibility to freezing and frozen storage (Rault et al., 2007), as well as to resistance to host biological barriers such as gastric acid and bile (Breeuwer \& Abee, 2000; Papadimitriou et al., 2006).

Cell counting and viability assessment, performed by FC, offers the advantage of process optimization according to the meaningful changes in FC observations, and provides important information on the mechanism of action of food processing treatments (Kennedy et al., 2011). For example, FC investigations on the mode of action of high hydrostatic pressure processing (HPP) and thermal treatments on Lactobacillus rhamnosus GG (LGG) and Bacillus subtilis pointed out significant differences between the treatments. In fact, these studies showed that heat inactivation was closely related to membrane disintegration, while pressure inactivation involved the damage of cellular transport system on dye accumulating cells (Ananta et al 2002; Doherty et al., 2010; Shen et al., 2009).

Moreover, multiparametric FC can highlight differences in the impact of processing treatments on the individual cells of microbial populations. Ritz et al. (2002), evaluating the effects of HPP on Listeria monocytogenes, observed that some of the pressurised cells had a membrane potential halfway between those of untreated and pressurised cells; this intermediate physiological state could be reversible in presence of a residual metabolic activity. On the other hand, results obtained by FC on a stressed Aeromonas hydrophila population at increasing concentrations of $\mathrm{NaCl}$ at different temperatures, evidenced the occurrence of stressed cells that maintained metabolic activity although they were not able to form colonies on agar plates, especially at 6\% $\mathrm{NaCl}$ (Pianetti et al., 2008).

In other studies on the impact of food processing on microbial populations, performed by FC, no evidence of sublethal injury was observed even when low number of viable cells survived (Uyttendaele et al., 2008).

Very recently, FC was used to detect the changes in microbial populations after exposure to ultraviolet radiation (Schenk et al., 2011). The profiles obtained using double staining techniques indicated that UV radiation produced significant damage in cytoplasmic membrane integrity and in cellular enzyme activity of Escherichia coli and Saccharomyces cerevisiae. Listeria innocua was the most resistant to UV-C radiation, with a VNC subpopulation due to membrane rupture.

FC has also been useful to identify markers for the transition between lag and growth phase in Bacillus cereus after exposure to near growth boundary acid stress for both strong and weak organic acids. In fact, the change in the signal of selected probes (cFDA, PI, C12resazurin and DiOC2(3)) was useful to detect esterase activity and electron transport chain activity, marking the exit from lag phase (Biesta-Peters et al., 2011).

Although multiparametric FC analysis is useful to determine the physiological state of the cells, it may overestimate microbial viability. Furthermore, FC requires the preparation of single cell suspensions because the presence of cell aggregates would provide a single 
cumulative signal, thus decreasing accuracy and producing misleading results (Nebe-vonCaron et al., 2000). However, this problem has been solved by means of sonication (Falcioni et al., 2006).

\section{Detection of foodborne pathogens}

\subsection{Overview of pathogens detection and identification}

Identification of pathogens is important in many scientific fields, especially in medicine and in food and environmental safety. As early detection of pathogens is often crucial, FC is a method of great interest, both in terms of rapidity and in potential automation. Researchers have shown a great interest in the application of FC in research on foodborne pathogens, as indicated by the increasing number of published papers in recent years (Table 1).

Pathogens detection by means of classical methods requires specific media, often with added antibiotics and supplements. This condition implies to know exactly the type of microorganism that has to be searched and its nutritional and environmental requirements. Moreover, pathogens often occur at low numbers, and therefore can usually be detected after pre-enrichment and selective enrichment, which are time-consuming.

One of the most important limits of classical plating methods is underestimation of unculturable cells. VNC pathogens are a critical issue in food safety studies, because they can retain their pathogenic potential without being detectable with classical plating methods. In addition, some slow-growing pathogens (e.g. mycobacteria) can require a very long time (even several days) to be isolated and counted on agar plates.

FC is a culture-independent technique, and therefore it has the great advantage of detecting microorganisms without the need of cultivation. The short time required for each analysis enables a near real-time pathogen detection in food samples. In general, FC exploits the different cell wall characteristics of bacteria to discriminate Gram-positives from Gramnegatives, thus providing information on Gram staining.

In Gram-negatives, the lipopolysaccharide outer membrane acts as an efficient permeability barrier to lipophilic molecules, and therefore to many dyes. Several approaches have been proposed to overcome this problem. Shapiro (2003) proposed the use of 1,11,3,3,31,31hexamethylindodicarbocyanine iodide $\left(\operatorname{DiIC}_{1}(5)\right)$, EDTA and carbonyl cyanide 3-chlorophenylhydrazone (CCCP): $\operatorname{DiIC}_{1}(5)$ is a membrane potential marker, EDTA is used to permeabilize the outer membrane to the entrance of dyes, and CCCP is a proton ionophore which reduces membrane potential to zero. Combining these stains, it was possible to correctly determine the Gram staining of many bacteria, including pathogens such as Staphylococcus aureus, Streptococcus pyogenes, Klebsiella pneumoniae, Pseudomonas aeruginosa and Salmonella Typhimurium.

FC is also useful for pathogen identification and fingerprinting in mixed populations, using fluorescent labelled DNA probes specific for 16S rRNA (Valdivia \& Falkow, 1998). For example, Lange et al. (1997) used rRNA probes to determine Pseudomonas species among other airborne contaminants. In fact, FC can analyse large volumes of food samples, and ribosomes are normally present in thousand copies in cells; hence, enough target sequences are available even without amplification. However, it is necessary to possess sequence information for bacteria identification, to develop the specific oligonucleotide probes, and for this reason some novel pathogens might remain undetected. 


\begin{tabular}{|c|c|c|c|}
\hline Microorganism & Probe & Aim of the study & References \\
\hline \multirow[t]{5}{*}{ Bacillus cereus } & $\begin{array}{l}\text { MitoSOX, SYTOX green, } \\
\text { CYTO } 9 \text { and } \\
\text { Carboxyfluorescein diacetate } \\
\end{array}$ & $\begin{array}{l}\text { Evaluation of responses to } \\
\text { heat stress exposure }\end{array}$ & $\begin{array}{l}\text { Mols et al., } \\
2011\end{array}$ \\
\hline & $\begin{array}{l}\text { Carboxyfluorescein diacetate, } \\
\text { Propidium iodide, C12 } \\
\text { Resazurin, } \\
\text { 3,3'-Diethyloxacarbocyanine } \\
\text { iodide }\end{array}$ & $\begin{array}{l}\text { Evaluation of cells after } \\
\text { exposure to near-growth- } \\
\text { boundary acid stress, and } \\
\text { markers for the transition } \\
\text { between lag phase and } \\
\text { growth }\end{array}$ & $\begin{array}{l}\text { Biesta-Peters } \\
\text { et al., } 2011\end{array}$ \\
\hline & $\begin{array}{l}\text { SYTO 9, Propidium iodide } \\
\text { and Carboxyfluorescein } \\
\text { diacetate }\end{array}$ & $\begin{array}{l}\text { Evaluation of the effect of } \\
\text { simulated cooking } \\
\text { temperatures and times on } \\
\text { endospores }\end{array}$ & $\begin{array}{l}\text { Cronin \& } \\
\text { Wilkinson, } \\
2008\end{array}$ \\
\hline & $\mathrm{DiOC}_{2}(3)$ & $\begin{array}{l}\text { Evaluation of the } \\
\text { antimicrobial activity of } \\
\text { valinomycin and cereulide }\end{array}$ & $\begin{array}{l}\text { Tempelaars } \\
\text { et al., } 2011\end{array}$ \\
\hline & $\begin{array}{l}\text { 3'-(p-Hydroxyphenyl) } \\
\text { fluorescein }\end{array}$ & $\begin{array}{l}\text { Evaluation of acid stress } \\
\text { resistance }\end{array}$ & $\begin{array}{l}\text { Mols et al., } \\
2010\end{array}$ \\
\hline \multirow[t]{3}{*}{ Escherichia coli } & $\begin{array}{l}\text { SYTO 9, Propidium iodide, } \\
\mathrm{DiOC}_{2}(3)\end{array}$ & $\begin{array}{l}\text { Evaluation of growth and } \\
\text { recovery rates in simulated } \\
\text { food processing treatment }\end{array}$ & $\begin{array}{l}\text { Kennedy } \\
\text { et al., } 2011\end{array}$ \\
\hline & $\begin{array}{l}\text { Propidium iodide and } \\
\text { Acridine orange }\end{array}$ & $\begin{array}{l}\text { Evaluation of the effect of } \\
\text { high-pressure carbon } \\
\text { dioxide (HPCD) }\end{array}$ & $\begin{array}{l}\text { Liao et al., } \\
2011\end{array}$ \\
\hline & $\begin{array}{l}\text { Propidium iodide and } \\
\text { SYTO } 9\end{array}$ & $\begin{array}{l}\text { Assessment of the } \\
\text { effectiveness of disinfection } \\
\text { on the amount of viable } \\
\text { bacteria in water } \\
\text { distribution }\end{array}$ & $\begin{array}{l}\text { Berney } \\
\text { et al., } 2007\end{array}$ \\
\hline \multirow[t]{3}{*}{$\begin{array}{l}\text { Escherichia coli } \\
\text { 0157:H7 }\end{array}$} & $\begin{array}{l}\text { SYTO 9, SYTO 13, SYTO 17, } \\
\text { SYTO } 40 \text { and Propidium } \\
\text { iodide }\end{array}$ & $\begin{array}{l}\text { Detection of viable but non } \\
\text { culturable (VNC) and } \\
\text { viable-culturable (VC) }\end{array}$ & $\begin{array}{l}\text { Khan et al., } \\
2010\end{array}$ \\
\hline & $\begin{array}{l}\text { Dihydrorhodamine } 123 \\
\text { (DHR 123) }\end{array}$ & $\begin{array}{l}\text { Study of the differential } \\
\text { effects of oxidative stress } \\
\text { using tea polyphenols }\end{array}$ & $\begin{array}{l}\text { Cui et al., } \\
2012\end{array}$ \\
\hline & $\begin{array}{l}\text { 5-Cyano-2,3-ditolyl } \\
\text { tetrazolium chloride (CTC), } \\
\text { Fluorescein isothiocyanate- } \\
\text { labelled antibodies }\end{array}$ & $\begin{array}{l}\text { Detection of respiring } E . \\
\text { coli O157:H7 in apple juice, } \\
\text { milk and ground beef }\end{array}$ & $\begin{array}{l}\text { Yamaguchi } \\
\text { et al., } 2003\end{array}$ \\
\hline $\begin{array}{l}\text { Listeria } \\
\text { monocytogenes }\end{array}$ & $\begin{array}{l}\text { Propidium iodide and } \\
\text { Carboxyfluorescein diacetate }\end{array}$ & $\begin{array}{l}\text { Effects of oregano, thyme } \\
\text { and cinnamon essential oils } \\
\text { on membrane and } \\
\text { metabolic activity }\end{array}$ & $\begin{array}{l}\text { Paparella } \\
\text { et al., } 2008\end{array}$ \\
\hline
\end{tabular}

Table 1. (continues on next page) 


\begin{tabular}{|c|c|c|c|}
\hline \multirow[t]{4}{*}{ Microorganism } & Probe & Aim of the study & References \\
\hline & $\begin{array}{l}\text { Propidium iodide, } \text { DiBAC }_{4}(3) \\
\text { and Carboxyfluorescein } \\
\text { diacetate }\end{array}$ & $\begin{array}{l}\text { Evaluation of the damage } \\
\text { of Listeria monocytogenes } \\
\text { cells treated by high } \\
\text { pressure for } 10 \text { min at } 400 \\
\text { MPa in pH } 5.6 \text { citrate buffer }\end{array}$ & $\begin{array}{l}\text { Ritz et al., } \\
2001\end{array}$ \\
\hline & $\begin{array}{l}\text { Propidium iodide and } \\
\text { Carboxyfluorescein diacetate }\end{array}$ & $\begin{array}{l}\text { Assessment of the effect } \\
\text { caused by the single } \\
\text { treatment of nisin and } \\
\text { mangainin II amide }\end{array}$ & $\begin{array}{l}\text { Ueckert } \\
\text { et al., } 1998\end{array}$ \\
\hline & $\begin{array}{l}\text { Dead/Live Baclight Bacterial } \\
\text { Viability Kit }{ }^{\mathrm{TM}}\end{array}$ & $\begin{array}{l}\text { Assessment of the } \\
\text { antimicrobial activity of the } \\
\text { bacteriocin leucocin B- } \\
\text { TA11a }\end{array}$ & $\begin{array}{l}\text { Swarts et al., } \\
1998\end{array}$ \\
\hline \multirow[t]{2}{*}{$\begin{array}{l}\text { Pseudomonas } \\
\text { aeruginosa }\end{array}$} & $\begin{array}{l}\text { SYTO 9, SYTO 13, SYTO 17, } \\
\text { SYTO } 40 \text { and Propidium } \\
\text { iodide }\end{array}$ & $\begin{array}{l}\text { Detection of viable but non } \\
\text { culturable (VNC) and } \\
\text { viable-culturable (VC) }\end{array}$ & $\begin{array}{l}\text { Khan et al., } \\
2010\end{array}$ \\
\hline & Dihydrorhodamine 123 & $\begin{array}{l}\text { Study of the differential } \\
\text { effects of oxidative stress } \\
\text { using tea polyphenols }\end{array}$ & $\begin{array}{l}\text { Cui et al., } \\
2012\end{array}$ \\
\hline \multirow[t]{3}{*}{\begin{tabular}{|l|} 
Salmonella \\
enterica serovar \\
Typhimurium \\
\end{tabular}} & $\begin{array}{l}\text { SYTO 9, SYTO 13, SYTO 17, } \\
\text { SYTO } 40 \text { and Propidium } \\
\text { iodide }\end{array}$ & $\begin{array}{l}\text { Detection of viable but non } \\
\text { culturable (VNC) and } \\
\text { viable-culturable (VC) }\end{array}$ & $\begin{array}{l}\text { Khan et al., } \\
2010\end{array}$ \\
\hline & $\begin{array}{l}\text { Propidium iodide and } \\
\text { SYTO } 9\end{array}$ & $\begin{array}{l}\text { Assessment of the } \\
\text { effectiveness of disinfection } \\
\text { methods in water } \\
\text { distribution systems }\end{array}$ & $\begin{array}{l}\text { Berney } \\
\text { et al., } 2007\end{array}$ \\
\hline & $\begin{array}{l}\text { Fluorescein isothiocyanate } \\
\text { (FITC)-labelled antibody and } \\
\text { Ethidium bromide }\end{array}$ & Detection in dairy products & $\begin{array}{l}\text { McClelland } \\
\text { \& Pinder, } \\
\text { 1994a }\end{array}$ \\
\hline \multirow[t]{2}{*}{$\begin{array}{l}\text { Staphylococcus } \\
\text { aureus }\end{array}$} & $\begin{array}{l}\text { SYTO 9, Propidium iodide } \\
\text { and } \mathrm{DiOC}_{2}(3)\end{array}$ & $\begin{array}{l}\text { Evaluation of growth and } \\
\text { recovery rates in simulated } \\
\text { food processing treatment }\end{array}$ & $\begin{array}{l}\text { Kennedy } \\
\text { et al., } 2011\end{array}$ \\
\hline & Dihydrorhodamine 123 & $\begin{array}{l}\text { Study on the differential } \\
\text { effects of oxidative stress } \\
\text { using tea polyphenols }\end{array}$ & $\begin{array}{l}\text { Cui et al., } \\
2012\end{array}$ \\
\hline
\end{tabular}

Table 1. (continued) Examples of studies on foodborne pathogens, performed by flow cytometry

Several research groups performed DNA fragment analysis by means of FC measurements. In particular, Kim et al. (1999) stained restriction fragments with a fluorescent intercalating dye that stoichiometrically binds to DNA; the amount of dye bound is therefore directly proportional to fragment length. Bacterial species discrimination is possible analysing DNA restriction fragments by FC, following a procedure similar to Pulsed Field Gel Electrophoresis (PFGE). 
Unique peak patterns were obtained for each bacterial species, which could be identified by comparing the fragment pattern with data from a fingerprinting library, with sizes from FC being in good agreement with sizes obtained by PFGE. This approach has some advantages with respect to PFGE, both in terms of shorter time of analysis, and in amount of DNA to be used. The FC method is effective but still hardworking, since requires DNA extraction. Some issues still have to be improved, beginning from rapid DNA extraction. Some authors (Suda \& Leitch, 2010) highlighted as cytosolic compounds can act as staining inhibitors, therefore affecting the stoichiometry of fluorochromes binding to DNA and the accuracy of genome size estimation. Therefore, it would be necessary to stabilize the DNA-fluorochrome complex or to protect DNA from staining inhibitors. Another useful method for pathogen identification takes advantage of autofluorescence of cellular components such as flavins, pigments, pyridines and aromatic amino acids, for discrimination among bacterial species (Valdivia \& Falkow, 1998).

Another important application is pathogen detection and counting (Comas-Riu \& Rius, 2009), where fluorescent staining has been widely used, obtaining strong signals and high specificity, even though antibodies and oligonucleotide applications are still limited when looking for many pathogenic strains or species at the same time. Salzmann et al. (1975) proposed a procedure for cell characterization without labelling, and later other authors demonstrated the feasibility of this method. In particular, Rajwa et al. (2008) unequivocally identified different bacterial strains, detecting signals of several light scattering angles. The choice of angles was determined by the fact that, as mentioned above, scattered light in the forward region first of all depends on refractive index and cell size, while side-scatter depends on the granularity of cellular structures and cell morphology. By using a classic flow cytometer with a compact enhanced scatter detector and Support Vector Machine (SVM)-based algorithms, only five angles of scatter and axial light loss were sufficient to identify Escherichia coli, Listeria innocua, Bacillus subtilis and Enterococcus faecalis with a success rate between 68 and $99 \%$. However, also this method cannot be used when the characteristics of the bioparticles to be analyzed are completely unknown, since different bacteria would presumably occupy the same measurement space.

\subsection{Microbial interactions}

In nature, microbes do not normally grow as planktonic single cells, but often interact in structured communities (i.e. biofilms), which affect individual cell behaviour. In particular, cells respond to environmental stimuli and to signals of neighbouring cells (Müller \& Davey, 2009). This aspect is particularly important for pathogens, since interactions among cells could somehow influence the development of infection.

Moreover, cells react to environmental stressors, modifying their pathogenic potential. Bacterial interaction and quorum sensing regulate virulence factors expression and also sporulation (Shapiro, 2003). Bacterial endospores can maintain a dormant condition for long periods with little or no metabolic activity, being resistant to thermal treatments and chemical preserving agents, commonly applied to food products. FC allows to distinguish between live and dead endospores on the basis of their scatter (Comas-Riu \& Rius, 2009; Stopa, 2000) or in combination with nucleic acid stain (Comas-Riu \& Vives Rego, 2002).

FC combined with image analysis provides new effective tools in studying individual cells and microbial interactions. Héchard et al. (1992) used FC to monitor interactions between 
Listeria monocytogenes and an anti-Listeria bacteriocin producer, belonging to Leuconostoc genus. Instead, Valdivia and Falkow (1996) applied FC and GFP (green fluorescent protein) to study bacteria and yeasts, with special attention to bacterial virulence genes. GFP is a protein that exhibits a green fluorescence when exposed to blue light; as this fluorescence is intrinsic to the protein and does not require substrates or enzymes, it is widely used to investigate protein localization. GFP is also a reliable reporter of gene expression in individual cells when fluorescence is measured by FC.

To study pathogen interaction with the target host cells, many authors labelled bacterial surfaces with fluorescent dyes such as fluorescein isothiocyanate, lucifer yellow or lipophilic dyes (Valdivia \& Falkow, 1998). Pathogen cells were then incubated with host cells and fluorescence was measured by FC. This method is very effective, quite simple, rapid and quantitative, since fluorescence intensity is proportional to the degree of pathogen association with host cells (Valdivia and Falkow, 1998). Finally, the capacity to perform the analysis without requiring microbial growth is particularly useful for fastidious pathogens (Dhandayuthapani et al., 1995).

\subsection{Pathogen detection in food microbiology}

Fluorescent labelled antibodies can be used for species-specific detection of pathogens in solutions, drinking water and foods. In an early study performed by FC in water samples, Tyndall et al. (1985) used fluorescein isothiocyanate-labelled antibodies and propidium iodide to detect Legionella spp. in cooling towers. Legionella pneumophila lives in water and is the etiologic agent of legionellosis. The major problem regarding water samples is that microorganisms are very diluted, and therefore a preliminary step of sample concentration is usually required. In that study, FC could detect the microorganism rapidly, even in unconcentrated samples.

Other authors (Tanaka et al., 2000) used a FC method to detect viable E. coli O157 in river water, combining fluorescent antibody staining and direct viable count, after incubation of cells with nutrients and quinolone antibiotics to prevent cell division and elongate nutrientresponsive cells (Kogure et al., 1979). Since the method requires some hours to elongate viable cells, the same authors proposed a procedure based on fluorescent antibody staining with cFDA and PI to detect esterase-active E. coli O157 cells in river water (Yamaguchi et al, 1997).

Due to their structure and composition, foods are very complex substrates for microbial detection by means of FC. In fact, pectins, proteins and lipids can interfere with analysis, requiring additional treatments of the sample. Gunasekera et al. (2000) reported the results of Escherichia coli and Staphylococcus aureus detection in milk, and pointed out the need of a preliminary treatment with proteinase $\mathrm{K}$ or savinase for UHT milk, and with savinase and Triton X-100 for raw milk.

Yamaguchi et al. (2003) developed a rapid method for E. coli O157:H7 detection in foods, based on fluorescein isothiocyanate-labelled specific antibodies. In apple juice, it was necessary to reduce background noise from non-bacterial particles, by means of repeated centrifugation steps, whereas a pretreatment with proteinase and Triton X-100 was necessary for milk, to reduce matrix interactions and to resolve signals from bacterial cells and from other particles, obtaining an excellent cell recovery. In solid food samples such as 
ground beef, several centrifugations at different speeds were needed to remove nonbacterial particles; however, only a poor recovery was reached, and detection limit was above $10^{3}$ cells/g, which can be too high for pathogens. In any case, FC analysis required much less time than microscopy to enumerate cells (2-3 hours).

Donnelly et al. (1988) used FC with fluorescent antibodies to detect Listeria monocytogenes in milk, and obtained $6 \%$ false-positive results and $0.53 \%$ false-negatives, compared with culture methods.

Assunção et al. (2007) applied FC to mycoplasmas detection in goat milk. Mycoplasmas isolation by means of culture techniques requires several days and is labour demanding. As these microorganisms are slow-growing, additional problems can occur due to fast-growing contaminants. By staining milk samples with the cell-permeant DNA-fluorochrome Sybr green I, mycoplasmas were distinguished from milk debris and from Staphylococcus aureus cells, with a detection limit of $10^{3}-10^{4}$ cells $/ \mathrm{ml}$. A similar detection limit $\left(10^{3}\right.$ cells $\left./ \mathrm{ml}\right)$ was found for Salmonella detection in eggs and milk, which is quite high in comparison with standard methods, able to detect 1 cell/25g (McClelland \& Pinder, $1994 \mathrm{a}, \mathrm{b}$ ). However, after enrichment in broth, FC sensitivity was strongly increased, reaching values below 1 cell $/ \mathrm{ml}$.

Ultimately, the advantages of FC with respect to conventional laboratory techniques are not only specificity and rapidity, but also a good correlation between FC enumeration and plate count in unprocessed food samples; however, as we show later on in this chapter, the correlation was different in other studies carried out on processed foods, mainly due to the presence of VNC cells. On the other hand, some problems still have to be solved, to eliminate or at least to reduce matrix interactions, to increase sensitivity, and to improve discrimination among different species.

\section{Commercial probes}

To reduce the time required for sample preparation and the quantity of reagents, many commercial kits have been developed. In particular, Molecular Probes (Invitrogen Life Technologies) has developed specific kits for cell viability assessment, cell counting and bacterial gram staining.

\subsection{Cell viability}

LIVE/DEAD ${ }^{\circledR}$ BacLight ${ }^{\mathrm{TM}}$ Bacterial Viability Kit (Molecular Probes, Invitrogen Life Technologies) is the best-known commercial probe for viability assessment. Two different nucleic acid-binding stains, SYTO 9 and propidium iodide, are used for a rapid discrimination between live bacteria with intact cytoplasmic membrane, and dead bacteria with compromised membranes. Membrane-permeant SYTO 9 labels live bacteria with green fluorescence, while membrane-impermeant propidium iodide labels membranecompromised bacteria with red fluorescence.

This probe is reliable and easy to use, and yields both viable and total count in one step. Moreover, the stains are supplied dry, without any harmful solvent, do not require refrigeration, and are chemically stable even in poor conditions. Probably, the most important advantage is that the reagents are simultaneously added to bacterial suspensions, then an incubation step of 5-10 minutes is necessary; as no washing is required, the total 
analysis time is strongly reduced. The results are easily acquirable, since the background remains virtually non-fluorescent and the contrast degree between green and red fluorescence is high (Comas-Riu \& Rius, 2009). Leuko et al. (2004) evidenced the high sensitivity and the robustness of this probe in extreme environments (e.g. hypersaline samples), and suggested a possible application for life detection in extraterrestrial halites.

However, under certain conditions, bacteria with compromised membranes may recover and reproduce, though they may be revealed as dead in the assay. In the meantime, bacteria with intact membranes and therefore scored as alive, may be unable to reproduce in nutrient medium (Boulos et al., 1999).

LIVE/DEAD ${ }^{\circledR}$ FungaLight ${ }^{\mathrm{TM}}$ Yeast Viability Kit (Molecular Probes, Invitrogen Life Technologies) works on the same basis of BacLight, discriminating yeast cells with intact or damaged membranes by means of SYTO 9 and propidium iodide. FungaLight CFDA AM/ Propidium iodide yeast vitality kit exploits the cell-permeant dye 5-carboxyfluorescein diacetate acetoxymethyl ester (CFDA AM) instead of SYTO 9, in combination with propidium iodide, to evaluate the viability of yeast cells by FC or microscopy. Esteraseactive yeasts with intact cell membranes stain fluorescent green, while cells with damaged membranes stain fluorescent red.

Other kits measure bacterial cells vitality by means of CCCP (sodium azide carbonyl cyanide 3-chlorophenylhydrazone), which marks reductase activity in Gram-positive and Gram-negative bacteria in BacLight ${ }^{\mathrm{TM}}$ RedoxSensor ${ }^{\mathrm{TM}}$ Green Vitality Kit, and CTC (5-cyano2,3-ditolyltetrazolium chloride), able to evaluate respiratory activity in BacLight ${ }^{\mathrm{TM}}$ RedoxSensorTM CTC Vitality Kit (Molecular Probes, Invitrogen Life Technologies).

Bacterial oxidation-reduction activity is an informative parameter for measuring cell vitality. The RedoxSensor ${ }^{\mathrm{TM}}$ green reagent penetrates both Gram-positive and Gramnegative bacteria, although differences in signal intensity may be observed based upon cell wall characteristics. In presence of reduction activity, the RedoxSensor ${ }^{\mathrm{TM}}$ green reagent produces a green-fluorescent signal in 10 minutes. This kit is useful for measuring the effects of antimicrobial agents and for monitoring cultures in fermenters.

By using BacLight ${ }^{\mathrm{TM}}$ RedoxSensor ${ }^{\mathrm{TM}}$ CTC Vitality Kit, respiring cells will absorb and reduce CTC into formazan, that is insoluble and red-fluorescent. Non-respiring and slow-respiring cells cause a lower reduction of CTC, and consequently produce less fluorescent product, giving a semiquantitative estimation. This kit has been used for the determination of respiring Escherichia coli in foods (Yamaguchi et al., 2003).

Finally, BacLight ${ }^{\mathrm{TM}}$ Bacterial Membrane Potential kit contains $\mathrm{DiOC}_{2}$, which exhibits green fluorescence at low concentrations in all bacterial cells, but becomes more concentrated in cells which maintain a membrane fluorescence and shows a shift of fluorescence emission towards red.

\subsection{Cell counting}

Conventional direct-count assays of bacterial viability are based on metabolic characteristics or membrane integrity. Both factors could give uncertain results, because of different growth and staining conditions. In addition, marked differences exist among many bacterial genera, in terms of morphology and physiology, so that a universally applicable assay is 
difficult to be obtained. For this reason, LIVE/DEAD ${ }^{\circledR}$ BacLight ${ }^{\mathrm{TM}}$ Bacterial Counting and Viability Kit (Molecular Probes, Invitrogen Life Technologies) has been developed, to count live and dead bacteria even in mixed populations. Based on SYTO 9 and propidium iodide, the kit contains a calibrated suspension of polystyrene microspheres as a standard for the volume of suspension analysed. Size and fluorescence of these beads have been chosen to be easily distinguished from stained bacteria. A fixed number of microsphere is added to the sample before the FC analysis, and the number of live and dead bacteria can be determined from the ratio bacteria events/microsphere events in the cytogram.

BacLight ${ }^{\mathrm{TM}}$ RedoxSensor ${ }^{\mathrm{TM}}$ CTC Vitality Kit (Molecular Probes, Invitrogen Life Technologies), previously described, is also useful to detect the respiratory activity of many bacterial populations. In this kit, the contextual presence of SYTO 24 and DAPI facilitate the differentiation of cells from debris and the calculation of total cell numbers.

As far as commercial flow cytometers are concerned, BactoScan ${ }^{\mathrm{TM}}$ (Foss) has become very popular in the milk industry worldwide. This instrument is widely used for total count assessment in milk, and has become the industrial standard for payment purposes. The major problems of FC analysis of milk, which are bacteria clusters and interference with milk components, have been solved by using a mechanical pretreatment of the sample. In this way, reliable results are obtained in less than nine minutes, at a capacity of up to 150 milk samples per hour.

\subsection{Gram staining}

Classical techniques for Gram staining require cell fixation. Some kits suitable for FC have been developed aimed at reducing the labour and the time required for samples preparation (fixing, washing, etc.). The LIVE ${ }^{\circledR}$ BacLight ${ }^{\mathrm{TM}}$ Bacterial Gram Stain Kit contains the greenfluorescent SYTO 9 and the red-fluorescent hexidium iodide nucleic acid stains. The two dyes differ in their spectral characteristics: Gram-positives fluoresce red-orange, while Gram-negatives fluoresce green. The kit gives the possibility to stain also mixed bacterial populations, and results can be obtained by FC or by any fluorescence microscope.

\section{Antimicrobial susceptibility testing}

\subsection{Conventional methods}

Besides detection and identification, the evaluation of antimicrobial susceptibility is an essential step in pathogen diagnostics, to select the therapeutic options.

Many methods are available for antimicrobial susceptibility testing (AST) such as disk diffusion and E-test, based on the same principle, broth or agar dilution test, breakpoint tests, and so on. These methods generally require an incubation time of about 18-24 hours to obtain the final results. Moreover, they are subjected to several sources of error, and therefore the correct performance of ASTs requires strict adherence to standardized protocols regarding culture medium, inoculum size, and preparation and incubation conditions. Generally, MIC (Minimal Inhibitory Concentrations) values are determined, not always corresponding to $\mathrm{MBC}$, which is the Minimal Bactericidal Concentration. In addition, a phenomenon known as postantibiotic effect, which is a transient inhibition of bacterial growth after drug removal, following exposure to an antimicrobial agent (Bigger, 
1944), often remains unconsidered. The same happens also for subinhibitory concentration effects, which is rarely determined, since this kind of analysis is tedious and timeconsuming (Álvarez-Barrientos et al., 2000).

Together with rapid detection and identification, also rapid susceptibility testing has a relevant clinical impact, especially for severe infections. In particular, the emergence of new pathogens and the increasing antibacterial drug resistance justify the need for rapid diagnostics.

\subsection{Early flow cytometry applications}

In the last decades automated systems have been developed to obtain AST results in few hours instead of 24 hours, as for traditional methods. However, several rapid methods provide information only on the average behaviour of bacterial populations and not on individual cells, which can be very heterogeneous in terms of age, growth rate and metabolism (Gant et al., 1993). This issue is particularly important, since antimicrobial susceptibility may be strongly influenced by individual growth rate and physiological state. Although cell age can be almost synchronized in laboratory conditions, individual differences are very common in vivo.

To solve this problem, many researchers have proposed the application of FC in ASTs. At the beginning of 1980s, it was proved (Steen et al., 1982) that the antimicrobial effect of rifampin could be detected by measuring light scattering and DNA content after only 10 minutes of drug incubation. Cohen \& Sahar (1989) used FC (light scatter and ethidium fluorescence) to identify and determine susceptibility to amikacin of bacteria from body fluids and exudates, in only one hour. However, in these studies, drug concentrations exceeded the MIC values of the tested microorganisms (Walberg et al., 1997). The effect of beta-lactams, even at sub-MIC concentrations, on E. coli DNA content was detected after 30 minutes of incubation (Martinez et al., 1982).

A different approach was applied by Durodie et al. (1995), who used the protein content/forward scatter ratio plotted as a function of time, as a reliable and sensitive indicator of the effect of several drugs (amoxicillin, mecillinam, chloramphenicol, ciprofloxacin and trimethoprim) at the sub-MIC value on E. coli cells. Although the ratio would theoretically appear more suitable for the detection of antibiotics affecting cell size or protein metabolism, it appeared to be valid for all the compounds studied, regardless the mode of action.

Gant et al. (1993) clearly demonstrated how the exposure of E. coli to several antibiotics with different mechanisms of action gave specific cytometer profiles. By staining cells with PI and measuring forward and side light scatter and fluorescence data by means of a FACScan flow cytometer, different three-dimensional patterns of events were obtained for gentamicin (active on ribosome and indirectly on cell membrane), ciprofloxacin (which inhibits DNA gyrase), and $\beta$-lactams (specifically acting on cell wall). PI intake indicates cell damage or defective outer membrane repair, and therefore it is more appropriate than ethidium bromide in FC evaluation of drugs susceptibility.

Other AST probes belong to the carbocyanine group. Carbocyanine dyes are positively charged and accumulate inside the cell; they give a measure of membrane depolarization, 
decreasing the fluorescence signal produced. Cells respond to different environmental conditions increasing or decreasing their membrane potential; cell death and/or membrane damage usually causes a collapse of the electrical potential. The dye [DiOC $5(3)]\left(3,3^{\prime}-\right.$ dipentyloxacarbocyanine iodide), previously used for measuring membrane potential in mammalian cells, was also employed to assess Staphylococcus aureus susceptibility to penicillin G and oxacillin (Ordóñez \& Wehman, 1993). Results were obtained in only 90 minutes after antibiotic exposure, and were comparable to those obtained by conventional susceptibility tests.

Rhodamine 123 and $\operatorname{DiBAC}_{4}(3)$ [bis (1,3-dibutylbarbituric acid) trimethine oxonol] are other membrane potential probes used in AST applications. In particular, rhodamine 123 is a cationic lipophilic dye, not taken up by Gram-negative bacteria and therefore used only for Gram-positives. It accumulates in cytosol of cells with an active transmembrane potential. On the contrary, oxonols are anionic lipophilic dyes that enter the cells with depolarized plasma membranes and bind to lipid-rich intracellular components. In this case, fluorescence-emitting cells have a low membrane potential; as membrane potential decreases, oxonol fluorescence intensity becomes higher. Moreover, differently from cationic dyes, anionic dyes are non-toxic for microorganisms, and thus can be successfully used in viability studies after exposure to antimicrobials. Another important advantage of oxonol is that it can be added directly to the culture in broth, avoiding pretreatment steps that may alter bacteria reactions or interfere with the antimicrobial effect (Álvarez-Barrientos et al., 2000). Mason et al (1995) used oxonol in studies on gentamicin and ciprofloxacin action, while Suller et al. (1997) chose this probe for a rapid determination of antibiotic susceptibility of methicillin-resistant Staphylococcus aureus.

Mortimer et al. (2000) compared three nucleic acid binding probes, and in detail PI, TOPRO-1 and SYTOX green, to detect antibiotic-induced injury in E. coli cells. TO-PRO-1 is a cyanine dye, generally used as DNA electrophoresis stain that can be useful as viability probe. SYTOX green is also a cyanine dye, which emits a strong fluorescence when bound to nucleic acid. All three dyes were able to detect antimicrobial activity; the intensity of fluorescence was related to the antibiotic mechanism of action, with small or no changes for cells treated with molecules acting on nucleic acid synthesis. Furthermore, in this case cellassociated fluorescence did not relate to results obtained by plate count. Therefore, although FC offers important insight into antimicrobial mechanism of action, the results are not always comparable with standard plate methods.

According to Gauthier et al. (2002), the agreement between FC results and microdilution and broth dilution tests was generally good or perfect for nine antibiotics tested on control strains and urinary tracts isolates (including Escherichia coli, Enterococcus faecalis, Staphylococcus aureus and S. epidermidis), but norfloxacin, nitrifurantoin and tetracycline gave high percentage $(65 \%)$ of discrepancies.

Together with SYTOX green, also SYTO 13 and SYTO 17, both labelling nucleic acids, were successfully used in FC studies (Comas \& Vives-Rego, 1997), but other authors (Lebaron et al., 1998) noticed that their binding sites could be degraded or modified in cells during a starvation period, suggesting a similar problem in presence of antimicrobials targeted at nucleic acids.

Other authors (Novo et al., 2000) pointed out that, although FC is a sensitive tool in monitoring dynamic cellular events, a single parameter would not be sufficient to determine 
the sensitivity to many different antimicrobial molecules. Therefore they proposed the contextual evaluation of membrane potential, membrane permeability and particle-counts of antibiotic treated and untreated S. aureus and Micrococcus luteus cells. Together with TO-PRO-3 and PI (membrane permeability indicators), the authors also used diethyloxacarbocyanine $\operatorname{DiOC}_{2}(3)$ and $\operatorname{DiBAC}_{4}(3)$ (membrane potential sensitive dyes), CCCP and valinomycin (ionophores), while bacterial count was calculated adding polystyrene beads to the sample at known concentration.

\subsection{Recent developments}

An innovative approach to improve FC efficiency in AST has been recently proposed by MiLeong et al. (2007). Antimicrobial testing of Orientia tsutsugamushi (a pathogen causing scrub typhus) by classical methods is not standardized, since viable cells are required and, as well as for other Rickettsia spp., intracellular pathogens require slow, labour-intensive and very expensive analysis. The authors used a monoclonal antibody to increase FC sensitivity in measuring cells growth.

FC is also useful for AST of Mycobacterium tuberculosis, and allows working with heat-killed cells, thus reducing health risks for operators. However, the method has to be improved, since poor correlation with traditional methods has been reported (Govender et a., 2010).

In a recent paper (Chau et al., 2011), FC and confocal microscopy were used to study the effect of daptomycin and telavancin, whose mechanism of action is still not completely clarified, on enterococci susceptible or resistant to vancomycin. This approach was useful in determining the drugs effect, and the physiological and morphological response of $E$. faecalis strains to cell wall-active antibiotics.

Due to the importance of antibiotic susceptibility determination, it is necessary to simplify cells preparation and reduce analysis time. Walberg et al. (1997) demonstrated the efficacy of cold-shock permeabilization (in PBS with EDTA and azide), which eliminates cell washing and reduce sample preparation time to less than five minutes. The results were comparable to ethanol fixation used in preparing cells for AST, although it was not applicable to cells exposed to gentamicin. Following this method, the total time of the analysis was less than one hour.

Several companies have developed new products to rapidly perform AST by FC. For example, BacLight ${ }^{\mathrm{TM}}$ (Molecular Probes, Invitrogen Life Technologies) has been used to study the antimicrobial effect of vancomycin on Enterococcus faecalis and E. faecium, by measuring fluorescence changes due to dead cells within three hours of incubation with antibiotic (Álvarez-Barrientos et al., 2000). Bio-Rad has developed a Flow Cytometric Antimicrobial Susceptibility Test (FAST kit), which does not rely on growth inhibition but on the rapid detection of the antimicrobial effect measured by a couple of fluorescent probes. Besides identifying susceptible and resistant microbes, FAST System could also be used to determine antimicrobial kinetics, synergy and dose response effects, with a good analytical performance. A Finnish research group (Jalava-Karvinen et al., 2009) has developed a fast method (BIS point method), based on FC immunophenotyping of phagocytes, able to discriminate between bacterial and viral infections in one hour. It is not always easy to distinguish between bacterial and viral infections on the basis of clinical symptoms, but the correct diagnosis is fundamental to start the appropriate therapy in short 
times. This fast method may prevent delay of therapy and inappropriate antibiotic treatments.

In conclusion, FC can be successfully used in AST, and is labour saving and often safer with respect to conventional methods. In addition, one of the most significant advantages of FC is the ability to point out microbial heterogeneity in response to antimicrobial agents. This is a fundamental issue in clinical microbiology, considering the possible presence of subpopulations less susceptible to drugs. Indeed, these features could be useful in food safety studies, to test susceptibility to chemical and physical agents or biopreservatives, and evaluate their mechanism of action.

\section{Applications to food preservation/biopreservation}

\subsection{Definitions}

Traditional food preservation technologies for pathogen control in foods rely on heat treatments, modifications of water activity and/or $\mathrm{pH}$, addition of chemical preservatives, and control of storage temperature. In recent years, as a result of the consumer demand for minimally processed products, other technologies are emerging as alternatives for shelf-life extension and pathogen control, e.g. high pressure processing (HPP), pulsed electric fields $(\mathrm{PEF})$, and ultraviolet light. Furthermore, the expanding interest in the green image of the food product promotes new preservation technologies, based on the use of natural compounds, which are commonly known as biopreservation technologies.

Biopreservation aims to prevent the contamination and growth of undesired microorganisms in foods, by addition of: a) antimicrobial compounds, naturally present in foods; b) antimicrobial compounds, produced in foods after physical or chemical stimulation, or after protective cultures addition (Stiles, 1996). This goal ought to be achieved without changing the sensory properties of the product (Holzapfel et al., 1995). In particular, food surface treatments with essential oils and plant extracts have been proposed for pathogen decontamination and/or control in packaging environments and clean rooms (Paparella et al., 2006).

\subsection{Conventional preservation technologies}

The ability of FC to discriminate different subpopulations on the basis of physiological characteristics of individual cells is particularly useful to assess the effects of preservation treatments on microbial survival. In fact, the success of most preservation technologies relies on ensuring metabolic exhaustion (Lee, 2004); as microbial stress reaction usually involves energy consumption, reduction of energy availability is considered a primary goal in food preservation.

The responses of E. coli, L. monocytogenes and S. aureus to various stressors, simulating food processing treatments, have recently been studied by Kennedy et al. (2011) by means of FC and FACS. The latter technique allowed to sort individual cells exposed to different stressors onto agar media, in order to evaluate growth under standard plating conditions. Stressors with the highest impact on plate count also showed the greatest effects on cell membrane integrity and membrane potential. However, treatments that impaired membrane permeability did not show necessarily a comparable impact on membrane 
potential. Moreover, the outcome of this study points out the complexity of the relationship between cytometric profiles and traditional plate count methods; in fact, cells with extensive damaged membranes were able to grow on agar plates, whereas in some cases the staining procedure rendered cells incapable of growth on solid media. For this reason, further protocol developments are needed for microbiological applications, to correlate FACSgenerated results with microbial viability.

Traditionally, the methods used to assess the performance of conventional food preservation technologies are based on the enumeration of viable cells using a standard plating technique. However, FC is emerging as a useful tool for the evaluation of the antimicrobial effects of preservation treatments. For example, the effects of osmotic shock on Escherichia coli and Staphylococcus aureus, after exposure to $\mathrm{NaCl}$ and sucrose, have been tested by $\mathrm{FC}$, using the fluorochromes SYTO 13 and calcein (Comas-Riu \& Vives-Rego, 1999); in this study, calcein proved to be a good marker for esterase activity in Staphylococcus aureus, whereas SYTO 13 was an efficient marker for plate counts.

FC is also considered a valuable tool for evaluating the effects of heat treatments by determining the percentages of dead, living and metabolically inactive cells (Comas \& Vives-Rego, 1998). In fact, quantification of viability beyond the traditional plating methods is deemed advisable not only in minimally processed foods, but also in conventional heat treatments. The bactericidal effects of different heat treatments have been demonstrated by FC (Kennedy et al., 2011), and heat treated samples have also been used as control populations in FC studies (Paparella et al., 2008; Boudhid et al., 2010).

Moreover, a flow cytometric assay has been successfully used to evaluate the efficacy of heat shock treatments $\left(30 \mathrm{~min}\right.$ at $\left.70^{\circ} \mathrm{C}\right)$ on Legionella strains in hospital water systems, where the mean percentage of viable cells and VNC cells varied from $4.6 \%$ to $71.7 \%$ (Allegra et al., 2011).

The heat stress response of Bacillus cereus has been recently studied by FC (Mols et al., 2011); by using the fluorescent probe MitoSOX, the authors confirmed the formation of superoxide in the cells after exposure to heat, and suggested that superoxide can play a role in the death of this microbial species during heat treatments. These findings correlate well with those reported by Cronin \& Wilkinson (2008), who observed an increasing proportion of membrane-damaged endospores of Bacillus cereus, with increasing heat treatment.

In Bacillus cereus, the acid stress response at $\mathrm{pH}$ values ranging from $\mathrm{pH} 5.4$ to $\mathrm{pH} 4.4$ with $\mathrm{HCl}$, was studied by Mols et al. (2010). FC analysis, after staining with the hydroxyl (OH.) and peroxynitrite $(\mathrm{ONOO}(-))$-specific fluorescent probe 3'-(p-hydroxyphenyl) fluorescein $(\mathrm{HPF})$, showed excessive radical formation in cells exposed to bactericidal conditions, suggesting an acid-induced malfunctioning of cellular processes that lead to cell death.

\subsection{Non-conventional preservation technologies}

Multiparameter FC has also been applied in food safety studies on pressure-assisted thermal sterilization, to analyse the physiological response of sporeformers to thermal inactivation and high pressure. Mathys et al. (2007) treated spores of Bacillus licheniformis by heat-only at $121^{\circ} \mathrm{C}$, by high pressure at $150 \mathrm{MPa}\left(37^{\circ} \mathrm{C}\right)$, or by a combined high pressure and heat treatment at $600 \mathrm{MPa}$ and $77^{\circ} \mathrm{C}$, and then dual stained the samples with the 
fluorescent dyes SYTO 16 and propidium iodide (PI). For pressure treated spores, but not heat-only treated spores, four distinct subpopulations were discriminated; in this respect, the authors suggested a three step model of inactivation involving a germination step following hydrolysis of the spore cortex, an unknown step, and finally an inactivation step with physical compromise of the inner membrane.

Likewise, FC methods have been developed to determine the germination rate of sporeformers. Cronin and Wilkinson (2007) stained Bacillus cereus endospores with SYTO 9 alone or cFDA, together with Hoechst 33342, after arresting germination at defined stages. FC was able to estimate the percentage of germinating and outgrowing endospores; in this study, cFDA/Hoechst 33342 staining was effective to measure overall germination rate, while SYTO 9 was useful to quantify ungerminated, germinating and outgrowing spores.

The efficacy of heat treatments can also be improved by ultrasound-assisted thermal processing (thermosonication), especially to minimize the undesired effects of conventional heat treatments on food quality. The bactericidal effect of thermosonication is affected by ultrasound amplitude, external static pressure, temperature, $\mathrm{pH}$, and substrate composition (Sala et al., 1995; Pagán et al., 1999). The impact of high-intensity ultrasound treatments (20 $\mathrm{kHz} ; 17.6 \mathrm{~W}$ ) on Escherichia coli cells was evaluated by Ananta et al. (2005), comparing FC results with plate count data. Although plate count results indicated a marked decrease of viability (D-value: $8.3 \mathrm{~min}$ ), PI intake data showed that only a small proportion of cells lost membrane integrity upon exposure to ultrasound for up to 20 minutes. Comparing cFDA and PI intake, the authors assumed that ultrasound induced damage on the lipopolysaccharide layer of the outer membrane of $E$. coli, as cFDA penetration apparently occurred without any cytoplasmic membrane integrity loss (PI negative). Based on these results, one interesting consideration is the possibility to combine ultrasound processing with biopreservatives, whose bactericidal activity is reduced by the presence of an intact outer membrane in Gram-negatives.

The resistance of microorganisms to high pressure processing (HPP) has been evaluated by FC methods. In HPP, one of the major problems is the possible underestimation of the number of viable cells that will grow during product shelf-life.

Ritz et al. (2001) used FC to evaluate the cellular damage on Listeria monocytogenes cells treated by high pressure for $10 \mathrm{~min}$ at $400 \mathrm{MPa}$ in $\mathrm{pH} 5.6$ citrate buffer. While no cell growth was observed after 48 hours on plate count agar, FC data obtained after staining with cFDA, PI and $\mathrm{DiBAC}_{4}$, revealed that cellular morphology was not really affected. In fact, cFDA intake indicated a dramatic decrease of esterase activity in treated cells, although such activity was not completely obliterated, and membrane integrity (PI) and membrane potential $\left(\mathrm{DiBAC}_{4}\right)$ were not evenly distributed across the cellular population. $\mathrm{DiBAC}_{4}$ probes, in combination with LIVE/DEAD ${ }^{\circledR}$ BacLight ${ }^{\mathrm{TM}}$ viability kit, were found to be good indicators of the viability of $E$. coli cells after long-term starvation (Rezaeinejad \& Ivanov, 2011).

\subsection{Biopreservation with essential oils and plant extracts}

Finally, the antibacterial activity of essential oils (EOs) in biopreservation strategies has been investigated by FC. The unprecedented interest in this specific application of FC is proved by the increasing number of published papers after 2008. In fact, the use of FC 
methods to evaluate the antibacterial activity of biopreserving agents can be considered a new approach, as the first documented application on food pathogens was published by Paparella et al. in 2008. Recently, FC has also been employed to evaluate the antifungal activity of coriander EO (Silva et al., 2011a) and lavender EO (Zuzarte et al., 2011) for the clinical treatment of fungal diseases. Nguefack et al. (2004) had used FC to estimate cell membrane permeability in Listeria innocua treated with three EOs at two concentrations. In their study, the EOs (Cymbopogon citratus, Ocimum gratissimum and Thymus vulgaris) were emulsified using 5\% (v/v) Tagat V20 in PBS, and added to L. innocua suspension, stained with cFDA. The treated cells were incubated at $37^{\circ} \mathrm{C}$, and the fluorescence intensity was measured by FC after 0-90 min. The fluorescence intensity of the cells exposed to EOs decreased faster than non-exposed cells, and this result was assumed to be due to cytoplasmic membrane permeabilization with cFDA leakage. However, FC data showed a reverse order of activity for the EOs compared with the diffusion assay, with C. citratus being more active than T. vulgaris and O. gratissimum.

Paparella et al. (2008) used FC to evaluate the physiological behaviour of L. monocytogenes after exposure to cinnamon, thyme and oregano EOs applied alone and in combination with $\mathrm{NaCl}$. The EOs were emulsified with $1 \%$ Tween 80 , sterilized by filtration, and added to vials containing PBS to obtain different final concentrations, ranging from 0.02 to $0.50 \% \mathrm{EO}$. After treatments, the cells were harvested by centrifugation, washed twice with PBS, and resuspended in PBS, to remove the EO. After double staining with PI and cFDA, three cell subpopulations were identified: PI positive, cFDA positive, and PI and cFDA positive, representing dead, viable and injured cells, respectively. Figure 1 illustrates the shifts in cell subpopulations of L. monocytogenes at increasing EOs concentrations: starting from Gate 4 (cFDA positive), they move to Gate 2 (cFDA and PI positive) to reach Gate 1 (PI positive) and finally Gate 3 (low fluorescence, most likely representing lysed cells).

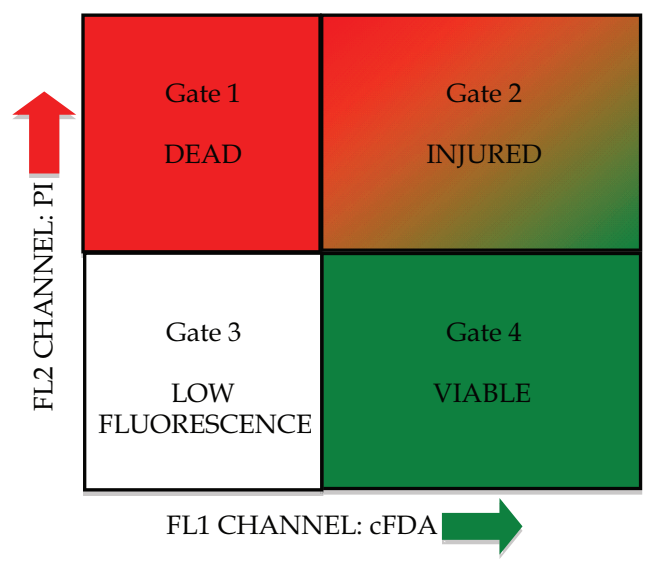

Fig. 1. Microbial subpopulations, after exposure to essential oils, evaluated by flow cytometry (dyes: carboxyfluorescein diacetate cFDA; propidium iodide PI)

According to FC results, membrane disintegration seemed to be the primary inactivation mechanism of oregano and thyme EOs, while a different mechanism of action was apparently involved in cinnamon EO treatments, with a lower activity and a minimal 
membrane damage. The outcome of this study also suggested that $\mathrm{NaCl}$ addition promoted membrane disintegration (PI positivity); the authors proposed that $\mathrm{NaCl}$ could increase vapour pressure and favour interaction between cell membrane and EOs, with a higher impact on membrane integrity.

Similar results were obtained by Muñoz et al. (2009), after treatment of L. monocytogenes with one extract of oregano EO. Viability evaluation, carried out by dual staining with PI and SYTO 9, revealed that live cell percentage decreased with exposure time, while the percentage of compromised cells remained constant and dead cells increased. Just as observed by Paparella et al. (2008) for cinnamon EO, in this study the comparison between plate count results and FC data suggested the presence of a viable but not culturable subpopulation, which was able to retain SYTO 9 but could not grow on Triptic Soy Broth containing Yeast Extract (TSBYE).

Evidence of VNC cells after EO treatments was found by Bouhdid et al. (2010), by using FC to investigate the mechanisms of action of cinnamon EO in Pseudomonas aeruginosa and Staphylococcus aureus cells. In this study, the authors compared the results obtained by plate counts, potassium leakage, transmission electron microscopy, and FC after staining with PI, CTC (metabolic activity) and bis-oxonol (membrane potential). Important differences in the effects of cinnamon EO in $P$. aeruginosa and $S$. aureus were observed, but in both cases membrane integrity did not appear to be the first target. In P. aeruginosa, cell death followed the decrease of respiratory activity, as indicated by the collapse of membrane potential, the loss of membrane-selective permeability, and PI accumulation. On the other hand, the antimicrobial activity against $S$. aureus was characterized by a marked decrease of metabolic activity and replication capacity, with cells entering a VNC state. On the basis of these findings, the activity of cinnamon EO against $S$. aureus appears to be due to the effects on membrane permeability, and namely to an increase of permeability to small ions like potassium; this membrane alteration impaired enzymatic activity but was not sufficient to allow PI intake.

The effect of rosemary EO on morphology and viability of S. aureus was investigated by Jiang et al. (2011), by comparing FC performed by PI staining, with Atomic Force Microscopy (AFM). The number of PI-positive events increased with increasing EO concentration, and AFM imaging revealed that the cell surface first became depressed, then the cell wall and cell membrane were damaged, and finally the cell was completely destroyed.

Membrane damage was also found to be the possible mechanism of action of coriander EO, in a recent FC study carried out by Silva et al. (2011b) on different Gram-positive and Gramnegative bacteria. This EO exerted bactericidal activity against all tested strains, with the exception of Bacillus cereus and Enterococcus faecalis. In sensitive strains, the antibacterial activity was indicated by PI incorporation and coexistent loss of other physiological functions such as membrane potential, efflux activity and respiratory activity.

Very recently, Cui et al. (2012) coupled FC and AFM to study morphological alterations in different microbial species, treated with a green tea polyphenol (EGCG) at sub-minimum inhibitory concentration. The comparison between FC data and AFM results showed an induced aggregation effect in Staphylococcus aureus and Staphylococcus mutans, and perforations in Pseudomonas aeruginosa and Escherichia coli O157:H7, with oxidative stress being confirmed by FC in Gram-negatives. 


\section{Conclusions}

FC is a powerful technique that has a great potential in food safety studies. The single-cell nature of this method makes it ideal for pathogen detection in food samples, where a complex microbial community is exposed to combinations of stressors.

Many areas of the food industry are highly automated, and require on-line monitoring of microbial parameters. This is particularly important in the manufacturing of perishable foods and beverages, where traditional methods have limited advantages. In fact, the use of FC is widespread in the milk industry for payment purposes, but would also provide relevant benefits for pathogen detection in other sectors, e.g. fresh-cut vegetables and fruits, raw meats, and seafood.

One of the reasons often cited as to why FC is not extensively used for routine microbiological analysis in the food industry is the cost of instrumentation and the need for specialized staff. Developments in optics and electronics, and possibly a market expansion, might open up new perspectives for applications both in quality control and in research and development.

In fact, FC can be considered a very versatile technique, which would be suitable to obtain real-time results in HACCP monitoring activities. In this respect, the main limitation is that plate count is still considered the gold standard for food producers, being the base for official analytical methods and microbiological criteria. However, researchers are investigating the reasons of the bias between the methods, and will presumably contribute to a better correlation between results.

Research and development is a new area of application for FC methods. Actually, product development projects are very labour-intensive but have to be performed in a short time, to keep up with a changing market. Therefore, FC is an ideal candidate for validation of new antimicrobial strategies in food formulations, as well as in disinfection and decontamination. Finally, together with other real-time devices (e.g. biosensors), FC might be able to offer new insight into process control, in particular in defining the set points of preserving and biopreserving technologies, to improve food safety.

\section{References}

Allegra S., Grattard F., Girardot F., Riffard S., Pozzetto B. \& Berthelot P. (2011). Longitudinal evaluation of the efficacy of heat treatment procedures against Legionella spp. in hospital water systems by using a flow cytometric assay. Applied and Environmental Microbiology 77(4): 1268-1275.

Álvarez-Barrientos A., Arroyo J., Cantón R., Nombela C. \& Sánchez-Pérez M. (2000). Applications of flow cytometry to clinical microbiology. Clinical Microbiology Reviews 13(2): 167-195.

Ananta E., Heinz V. \& Knorr D. (2004). Assessment of high pressure induced damage on Lactobacillus rhamnosus GG by flow cytometry. Food Microbiology 21: 567-577.

Ananta E., Voigt D., Zenker M., Heinz V. \& Knorr D. (2005). Cellular injuries upon exposure of Escherichia coli and Lactobacillus rhamnosus to high-intensity ultrasound. Journal of Applied Microbiology 99: 271-278. 
Assunção P., Davey H.M., Rosales R.S., Antunes N.T., de la Fe C., Ramirez A.S., Ruiz de Galarreta C.M. \& Poveda J.B. (2007). Detection of mycoplasmas in goat milk by flow cytometry. Cytometry part A 71A: 1034-1038.

Attfield P., Gunasekera T., Boyd A., Deere D. \& Veal D. (1999). Applications of flow cytometry to microbiology of food and beverage industries. Australasian Biotechnology 9: 159-166.

Battye F.L., Light A. \& Tarlinton D.M. (2000). Single cell sorting and cloning. Journal of Immunological Methods 243: 25-32.

Ben Amor K., Breeuwer P., Verbaarschot P., Rombouts F.M., Akkermans A.D.L., De Vos W.M. \& Abee T. (2002). Multiparametric flow cytometry and cell sorting for the assessment of viable, injured, and dead Bifidobacterium cells during bile salt stress. Applied and Environmental Microbiology 68(11): 5209-5216.

Berney M., Weilenmann H.U. \& Egli T. (2006). Flow-cytometric study of vital cellular functions in Escherichia coli during solar disinfection (SODIS). Microbiology 152: 1719-1729.

Berney M., Hammes F., Bosshard F., Weilenmann H.U. \& Egli T. (2007). Assessment and interpretation of bacterial viability by using the LIVE/DEAD BacLight Kit in combination with flow cytometry. Applied and Environmental Microbiology 73(10): 3283-3290.

Berney M., Vital M., Hülshoff I., Weilenmann H.U., Egli T. \& Hammes F. (2008). Rapid, cultivation-independent assessment of microbial viability in drinking water. Water Research 42(14): 4010-4018.

Bergquist P.L., Hardiman E.M., Ferrari B.C. \& Winsley T. (2009). Applications of flow cytometry in environmental microbiology and biotechnology. Extremophiles 13: 389401.

Biesta-Peters E.G., Mols M., Reij M. W. \& Abee T. (2011). Physiological parameters of Bacillus cereus marking the end of acid-induced lag phases. International Journal of Food Microbiology 148: 42-47.

Bigger J.W. (1944). The bactericidal action of penicillin on Staphylococcus pyogenes. Irish Journal of Medical Science 227: 533-568.

Bouhdid S., Abrini J., Amensour M., Zhiri A., Espuny M.J. \& Manresa A. (2010). Functional and ultrastructural changes in Pseudomonas aeruginosa and Staphylococcus aureus cells induced by Cinnamonum verum essential oil. Journal of Applied Microbiology 109: 1139-1149.

Boulos L., Prévost M., Barbeau B., Coallier J. \& Desjardins R. (1999). LIVE/DEAD ${ }^{\circledR}$ BacLight ${ }^{\mathrm{TM}}$ : application of a new rapid staining method for direct enumeration of viable and total bacteria in drinking water. Journal of Microbiological Methods 37: 7786.

Breeuwer P., Drocourt J.L., Rombouts F.M. \& Abee T. (1994). Energy dependent, carriermediated extrusion of carboxyfluorescein from Saccharomyces cerevisiae allows rapid assessment of cell viability by flow cytometry. Applied Environmental Microbiology 60: 1467-1472.

Breeuwer P. \& Abee, T. (2000). Assessment of viability of microorganisms employing fluorescence techniques. International Journal of Food Microbiology 55: 193-200.

Breeuwer P. \& Abee T. (2004). Assessment of the membrane potential, intracellular pH and respiration of bacteria employing fluorescence techniques. In: Molecular Microbial 
Ecology Manual Kowalchuk G. A., De Bruijn F. J. Head I.M., Akkermans A.D. \& van Elsas J.D. (Eds)., pp. 1563-1579, Springer. ISBN 978-1-4020-4860-9.

Bunthof C. J., Bloemen K., Breeuwer P., Rombouts F.M. \& Abee T. (2001). Flow cytometric assessment of viability of lactic acid bacteria. Applied and Environmental Microbiology 67(5): 2326-2335.

Chau F., Lefort A., Benadda S., Dubée V. \& Fantin B. (2011). Flow cytometry as a tool to determine the effects of cell wall-active antibiotics on vancomycin -susceptible and -resistant Enterococcus faecalis strains. Antimicrobial agents and chemotherapy 55(1): 395-398.

Chen S., Ferguson L.R., Shu Q. \& Garg S. (2011). The application of flow cytometry to the characterisation of a probiotic strain Lactobacillus reuteri DPC16 and the evaluation of sugar preservatives for its lyophilisation. LWT Food Science and technology 44: 1973-1879.

Comas J. \& Vives-Rego J. (1997). Assessment of the effects of gramicidin, formaldehyde and surfactants on Escherichia coli by flow cytometry using nucleic acid and membrane potential dyes. Cytometry 29: 58-64.

Comas J. \& Vives-Rego J. (1998). Enumeration, viability and heterogeneity in Staphylococcus aureus cultures by flow cytometry. Journal of Microbiological Methods 32: 45-53.

Comas-Riu J. \& Vives-Rego J. (1999). Use of calcein and SYTO-13 to assess cell cycle phases and osmotic shock effects on Escherichia coli and Staphylococcus aureus by flow cytometry. Journal of Microbiological Methods (34): 215-221.

Comas-Riu J. \& Vives-Rego J. (2002). Cytometric monitoring growth, sporogenesis and spore cell sorting in Paenibacillus polymyxa (formerly Bacillus polymyxa). Journal of Applied Microbiology 92: 475-481.

Comas-Riu J. \& Rius N. (2009). Flow cytometry applications in the food industry. Journal of Industrial Microbiology and Biotechnology 36: 999-1011.

Cram L.S. (2002). Flow cytometry, an overview. Methods in Cell Science 24: 1-9.

Cronin U.P. \& Wilkinson M.G. (2007). The use of flow cytometry to study the germination of Bacillus cereus endospores. Cytometry Part A 71A: 143-153.

Cronin, U.P. \& Wilkinson, M.G. (2008). Bacillus cereus endospores exhibit a heterogeneous response to heat treatment and low-temperature storage. Food Microbiology 25(2): 235-243.

Cui Y., Oh Y.J., Lim J., Youn M., Lee I., Pak H.K., Park W., Jo W., \& Park S. (2012). AFM study of the differential inhibitory effects of the green tea polyphenol b (-)epigallocatechin-3-gallate (EGCG) against Gram-positive and Gram-negative bacteria. Food Microbiology 29(1): 80-87.

Davey H.M. (2002). Flow cytometric techniques for the detection of microorganisms. Methods in Cell Science 24: 91-97.

Davey H.M., Jones A., Shaw A.D., Kell D.B. (1999). Variable selection and multivariate methods for the identification of microorganisms by flow cytometry. Cytometry 35: 162-168.

Davey H.M. \& Kell D.B. (1996). Flow cytometry and cell sorting of heterogeneous microbial populations: the importance of single-cell analyses. Microbiological Reviews 60: 641696.

Delong E.F., Wickham G.S. \& Pace N.R. (1989). Phylogenetic stains - ribosomal RNA-based probes for the identification of single cells. Science 243: 1360-1363. 
Dhandayuthapani S, Via L.E., Thomas C.A., Horowitz P.M., Deretic D. \& Deretic V. (1995). Green fluorescent protein as a marker for gene expression and cell biology of mycobacterial interactions with macrophages. Molecular microbiology 17: 901-912.

Doherty S.B., Wang L., Ross R.P., Stanton C., Fitzgerald G.F. \& Brodkorb A. (2010). Use of viability staining in combination with flow cytometry for rapid viability assessment of Lactobacillus rhamnosus GG in complex protein matrices. Journal of Microbiological Methods 82: 301-310.

Donnelly C.W., Baigent G.J. \& Briggs E.H. (1988). Flow cytometry for automated analysis of milk containing Listeria monocytogenes. Journal of the Association of Official Analytical Chemistry 71: 655-658.

Dupont C. \& Augustin J. C. (2009). Influence of stress on single-cell lag time and growth probability for Listeria monocytogenes in Half Fraser Broth. Applied and Environmental Microbiology 75(10): 3069-3076.

Durodie J., Coleman K., Simpson I.N., Loughborough S.H. \& Winstanley D.W. (1995). Rapid detection of antimicrobial activity using flow cytometry. Cytometry 21: 374-377.

Falcioni T., Manti A., Boi P., Canonico B., Balsamo M. \& Papa S. (2006). Comparison of disruption procedures for enumeration of activated sludge floc bacteria by flow cytometry. Cytometry Part B 70B: 149-153.

Freese H.M., Karsten U. \& Schumann R. (2006). Bacterial abundance, activity, and viability in the eutrophic River Warnow, Northeast Germany. Microbial Ecology 51: 117-127.

Gant V.A., Warnes G., Phillips I. \& Savidge G.F. (1993). The application of flow cytometry to the study of bacterial responses to antibiotics. Journal of Medical Microbiology 39: 147-154.

Gauthier C., St-Pierre Y. \& Villemur R. (2002). Rapid antimicrobial susceptibility testing of urinary tract isolates and samples by flow cytometry. Journal of Medical Microbiology 51: 192-200.

Govender S., du Plessis S.J., van de Venter M. \& Hayes C. (2010). Antibiotic susceptibility of multi-drug resistant Mycobacterium tuberculosis using flow cytometry. Medical Technology SA 24(2): 25-28.

Gunasekera T.S., Attfield P.V. \& Veal D.A. (2000). A flow cytometry method for rapid detection and enumeration of total bacteria in milk. Applied and Environmental Microbiology 66(3): 1228-1232.

Hammes F. \& Egli T. (2010). Cytometric methods for measuring bacteria in water: advantages, pitfalls and applications Analytical and Bioanalytical Chemistry 397(3): 1083-1095.

Héchard Y., Jayat C., Letellier F., Julien R., Cenatiempo Y. \& Ratinaud M.H. (1992). On-line visualization of the competitive behavior of antagonistic bacteria. Applied and Environmental Microbiology 58(11): 3784-3786.

Hewitt C. J \& Nebe-von-Caron G. (2001). An industrial application of multiparameter flow cytometry: assessment of cell physiological state and its application to the study of microbial fermentations. Cytometry 44: 179-187.

Holzapfel W.H., Geisen R. \& Schillinger U. (1995). Biological preservation of foods with reference to protective cultures, bacteriocins and food-grade enzymes. International Journal of Food Microbiology 24: 343-362.

Jalava-Karvinen P., Hohenthal U., Laitinen I., Kotilainen P., Rajamäki A., Nikoskelainen J., Lilius E.M. \& Nuutila J. (2009). Simultaneous quantitative analysis of FcүRI (CD64) 
and CR1 (CD35) on neutrophils in distinguishing between bacterial infections, viral infections, and inflammatory diseases. Clinical Immunology 133(3): 314-323.

Jiang Y., Wu N., Fu Y.J., Wang W., Luo M., Zhao C.J., Zu Y.G., Liu X.L. (2011). Chemical composition and antimicrobial activity of the essential oil of Rosemary. Environmental Toxicology and Pharmacology 32: 63-68.

Kaprelyants A.S., Mukamolova G.V., Davey H.M. \& Kell D.B. (1996). Quantitative analysis of the physiological heterogeneity within starved cultures of Micrococcus luteus by flow cytometry and cell sorting. Applied and Environmental Microbiology 62(4): 13111316.

Kastbjerg V.G., Nielsen D.S., Arneborg N. \& Gram L. (2009). Response of Listeria monocytogenes to disinfection stress at the single-cell and population levels as monitored by intracellular $\mathrm{pH}$ measurements and viable-cell counts. Applied Environmental Microbiology 75(13): 4550-4556.

Katsuragi T. \& Tani Y.(2000). Screening for microorganisms with specific characteristics by flow cytometry and single-cell sorting. Journal of Bioscience and Bioengineering 89: 217-222.

Kennedy D., Cronin U.P. \& Wilkinson M.G. (2011). Responses of Escherichia coli, Listeria monocytogenes, and Staphylococcus aureus to simulated food processing treatments, determined using Fluorescence-Activated Cell Sorting and plate counting. Applied and Environmental Microbiology 77 (13): 4657-4668.

Khan M.M., Pyle B.H. \& Camper A.K. (2010). Specific and rapid enumeration of viable but non culturable and viable-culturable gram-negative bacteria by using flow cytometry. Applied and Environmental Microbiology 76(15): 5088-5096.

Kim Y., Jett J.H., Larson E.J., Penttila J.R., Marrone B.L. \& Keller R.A. (1999). Bacterial fingerprinting by flow cytometry: bacterial species discrimination. Cytometry 36: 324-332.

Kogure K., Simidu U. \& Taga N. (1979). A tentative direct microscopic method for counting living marine bacteria. Canadian Journal of Microbiology 25(3): 5415-420.

Lange J.L., Thorne P.S. \& Lynch N. (1997). Application of flow cytometry and fluorescent in situ hybridization for assessment of exposures to airborne bacteria. Applied and Environmental Microbiology 63(4): 1557-1563.

Lebaron P., Catala P. \& Parthuisot N. (1998). Effectiveness of SYTOX green stain for bacterial viability assessment. Applied and Environmental Microbiology 64(7): 2697-2700.

Lee S.Y. (2004). Microbial safety of pickled fruits and vegetables and hurdle technology. Internet Journal of Food Safety 4: 21-32.

Leuko S., Legat A., Fendrihan S. \& Stan-Lotter H. (2004). Evaluation of the LIVE/DEAD BacLight kit for detection of extremophilic Archaea and visualization of microorganisms in environmental hypersaline samples. Applied Environmental Microbiology 70(11): 6884-6886.

Lew S., Lew M., Mieszczyński T. \& Szarek J. (2010). Selected fluorescent techniques for identification of the physiological state of individual water and soil bacterial cells. Folia Microbiologica 55(2): 107-118.

Liao H., Zhang F., Hu X. \& Liao X (2011). Effects of high-pressure carbon dioxide on proteins and DNA in Escherichia coli. Microbiology 157(3): 709-720. 
Manti A., Boi P., Amalfitano S., Puddu A. \& Papa S. (2011). Experimental improvements in combining CARD-FISH and flow cytometry for bacterial cell quantification. Journal of Microbiological Methods, doi:10.1016/j.mimet.2011.09.003

Martinez O.V., Gratzner H.G., Malinin T.I. \& Ingram M. (1982). The effect of some $\beta$ - lactam antibiotics on $E$. coli studied by flow cytometry. Cytometry 3: 129-133.

Mason D.J., Allman R., Stark J.M. \& Lloyd D (1995). The application of flow cytometry to the estimation of bacterial antibiotic susceptibility. Journal of Antimicrobial Chemotherapy 36: 441-443

Mathys A., Chapman B., Bull M., Heinz V. \& Knorr D. (2007). Flow cytometric assessment of Bacillus spore response to high pressure and heat. Innovative Food Science and Emerging Technologies 8: 519-527.

McClelland R.G. \& Pinder A.C. (1994a). Detection of Salmonella typhimurium in dairy products with flow cytometry and monoclonal antibodies. Applied Environmental Microbiology 60(12): 4255-4262.

McClelland R.G. \& Pinder A.C. (1994b). Detection of low levels of specific Salmonella species by fluorescent antibodies and FC. Journal of Applied Bacteriology 77: 440-447.

Michels M. \& Bakker. E.P. (1985). Generation of a large, protonophore-sensitive proton motive force and $\mathrm{pH}$ difference in the acidophilic bacteria Thermoplasma acidophilum and Bacillus acidocaldarius. Journal of Bacteriology 161: 231-237.

Mi-Jeong K., Mee-Kyung K. \& Jae-Sung K (2007). Improved antibiotic susceptibility test of Orientia tsutsugamushi by FC using a monoclonal antibody. Journal of Korean Medical Science 22: 1-6.

Mols M., van Kranenburg R., van Melis C.C. Moezelaar R., and Abee T. (2010). Analysis of acid-stressed Bacillus cereus reveals a major oxidative response and inactivationassociated radical formation. Environmental Microbiology 12 (4): 873-885.

Mols M., Ceragioli M. \& Abee T. (2011). Heat stress lead to superoxide formation in Bacillus cereus detected using the fluorescent probe MitoSOX. International Journal of Food Microbiology 151: 119-122.

Mourant J.R., Freyer J.P., Hielscher A.H., Eick A.A., Shen D. \& Johnson T.M. (1998). Mechanisms of light scattering from biological cells relevant to noninvasive opticaltissue diagnostics. Applied Optics 37(16): 3586-3593.

Müller S. \& Davey H. (2009). Recent advances in the analysis of individual microbial cells. Cytometry part A 75A: 83-85.

Muñoz M., Guevara L., Palop A., Tabera J. \& Fernández P.S. (2009). Determination of the effect of plant essential oils obtained by supercritical fluid extraction on the growth and viability of Listeria monocytogenes in broth and food systems using flow cytometry. LWT - Food Science and Technology 42: 220-227.

Nebe-von-Caron G., Stephens P.J., Hewitt C.J., Powell J.R. \& Badley R.A. (2000). Analysis of bacterial function by multi-colour fluorescence flow cytometry and single cell sorting. Journal of Microbiological Methods 42: 97-114.

Neidhardt F.C., VanBogelen R.A. (2000). Proteomic analysis of bacterial stress response. In: Bacterial stress responses, Storz G. \& Hengge-Aronis R. (Eds.), pp. 445-452, ASM Press. ISBN 978-1-55581-621-6, Washington D.C.

Nguefack J., Budde B.B. \& Jakobsen M. (2004). Five essential oils from aromatic plants of Cameroon: their antibacterial activity and ability to permeabilize the cytoplasmic 
membrane of Listeria innocua examined by flow cytometry. Letters in Applied Microbiology 39: 395-400.

Nocker A., Caspers M., Esveld-Amanatidou A., van der Vossen J., Schuren F., Montijn R. \& Kort R. (2011). Multiparameter viability assay for stress profiling applied to the food pathogen Listeria monocytogenes F2365. Applied and Environmental Microbiology 77(18): 6433-6440.

Novo D.J., Perlmutter N.G., Hunt R.H. \& Shapiro H.M. (2000). Multiparameter flow cytometric analysis of antibiotic effects on membrane potential, membrane permeability and bacterial counts of Staphylococcus aureus and Micrococcus luteus. Antimicrobial agents and chemotherapy 44(4): 827-834.

Ordóñez J.V \& Wehman N.W. (1993). Rapid flow cytometric antibiotic susceptibility assay for Staphylococcus aureus. Cytometry 14: 811-818.

Pagán R., Mañas P., Raso J. \& Condón S. (1999). Bacterial resistance to ultrasonic waves under pressure at nonlethal (manosonication) and lethal (thermomanosonication) temperatures. Applied and Environmental Microbiology 65(1): 297-300.

Papadimitriou K., Pratsinis H., Nebe-von-Caron G., Kletsas D. \& Tsakalidou E. (2006). Rapid assessment of the physiological status of Streptococcus macedonicus by flow cytometry and fluorescence probes. International Journal of Food Microbiology 111: 197-205.

Paparella A., Taccogna L., Chaves López C., Serio A., Di Berardo L. \& Suzzi G. (2006). Food biopreservation in clean rooms. Italian Journal of Food Science, special issue Convegno Nazionale: Aspetti microbiologici degli alimenti confezionati, 43-52.

Paparella A., Taccogna L., Aguzzi I., Chaves López C., Serio A., Marsilio F. \& Suzzi G. (2008). Flow cytometric assessment of the antimicrobial activity of essential oils against Listeria monocytogenes. Food Control 19: 1174-1182.

Pianetti A., Manti A., Boi P., Citterio B., Sabatini L., Papa S., Bruno M., Rocchi L. \& Bruscolini F. (2008). Determination of viability of Aeromonas hydrophila in increasing concentrations of sodium chloride at different temperatures by flow cytometry and plate count technique. International Journal of Food Microbiology 127: 252-260.

Quirós C., Herrero M., García L.A. \& Díaz M. (2007). Application of flow cytometry to segregated kinetic modelling based on the physiological states of microorganisms. Applied and Environmental Microbiology 73(12): 3993-4000.

Rajwa B., Venkatapathi M., Ragheb K., Banada P.P., Hirleman E.D., Lary T. \& Robinson J.P. (2008). Automated classification of bacterial particles in flow by multiangle scatter measurement and support vector machine classifier. Cytometry part A 73A: 369-379.

Rault A., Béal C., Ghorbal S., Ogier J-C. \& Bouix M. (2007). Multiparametric flow cytometry allows rapid assessment and comparison of lactic acid bacteria viability after freezing and during frozen storage. Cryobiology 55: 35-43.

Rezaeinejad S. \& Ivanov V. (2011). Heterogeneity of Escherichia coli population by respiratory activity and membrane potential of cells during growth and long-term starvation. Microbiological Research 166: 129-135.

Richard H. \& Foster. J.W. (2004). Escherichia coli glutamate- and arginine-dependent acid resistance systems increase internal $\mathrm{pH}$ and reverse transmembrane potential. Journal of Bacteriology 186: 6032-6041. 
Ritz M., Tholozan J.L., Federighi M. \& Pilet M.F. (2001). Morphological and physiological characteristics of Listeria monocytogenes subjected to high hydrostatic pressure. Applied and Environmental Microbiology 67(5): 2240-2247.

Roszak D.B., Grimes D.J. \& Colwell, R.R. (1984). Viable but nonrecoverable stage of Salmonella enteritidis in acquatic systems. Canadian Journal of Microbiology 30: 334338.

Sala F.J., Burgos J., Condón S., López P. \& Raso J. (1995). Effect of heat and ultrasound on microorganisms and enzymes. In: New Methods of Food Preservation, Gould G.W. (Ed.), pp. 176-204, Blackie Academic \& Professional London, ISBN: 0- 8342-1341-9, UK.

Salzmann G.C., Crowell J.M. \& Mullaney P.F. (1975). Flow-system multi-angle lightscattering instrument for biological cell characterization. Journal of the Optical Society of America 24: 284-291.

Schenk M., Raffellini S., Guerrero S., Blanco G.A. \& Alzamora S.M. (2011). Inactivation of Escherichia coli, Listeria innocua and Saccharomyces cerevisiae by UV-C light: Study of cell injury by flow cytometry. LWT - Food Science and Technology 44: 191-198.

Schmid I., Krall W.J., Uittenbogaart C.H., Braun J. \& Giorgi J.V. (1992). Dead cell discrimination with 7-amino-actinomycin $\mathrm{D}$ in combination with dual color immunofluorescence in single laser flow cytometry. Cytometry 13: 204-208.

Shapiro H.M. (2003). Practical Flow Cytometry (fourth edition). Wiley-Liss, ISBN: 9780471411253, Hoboken, New Jersey.

Shen T., Bos A.P. \& Brul, S. (2009). Assessing freeze-thaw and high pressure low temperature induced damage to Bacillus subtilis cells with flow cytometry. Innovative Food Science and Emerging Technologies 10: 9-15.

Silva F., Ferreira S., Duarte A., Mendonça D.I. \& Domingues F.C. (2011a). Antifungal activity of Coriandrum sativum essential oil, its mode of action against Candida species and potential synergism with amphotericin B. Phytomedicine doi: 10.1016/j.phymed.2011.06.033.

Silva F., Ferreira S., Queiroz J.A. \& Domingues F.C. (2011b). Coriander (Coriandrum sativum L.) essential oil: its antibacterial activity and mode of action evaluated by flow cytometry. Journal of Medical Microbiology 60: 1479-1486.

Steen H.B. (2000). Flow cytometry of bacteria: glimpses from the past with a view to the future. Journal of Microbiological Methods 42: 65-74.

Steen H.B., Boye E., Skarstad K., Bloom B., Godal T. \& Mustafa S. (1982). Applications of flow cytometry on bacteria: Cell cycle kinetics, drug effects and quantitation of antibody binding. Cytometry 2, 249-257.

Stiles, M.E. (1996). Biopreservation by lactic acid bacteria. Antonie van Leeuwenhoek 70: 331345.

Stopa P.J. (2000). The flow cytometry of Bacillus anthracis spores revisited. Cytometry 41: 2327-2440.

Sträuber H. \& Müller S. (2010). Viability states of bacteria - specific mechanisms of selected probes. Cytometry Part A 77A: 623-634.

Suda J. \& Leitch I.J. (2010). The quest for suitable reference standards in genome size research. Cytometry part A 77A: 717-720. 
Sueller M.T.E., Stark J.M. \& Lloyd D. (1997). A flow cytometric study of antibiotic-induced damage and evaluation as a rapid antibiotic susceptibility test for methicillinresistant Staphylococcus aureus. Journal of Antimicrobial Chemotherapy 40: 77-83.

Swarts A.J., Hastings J.W., Roberts R.F. \& von Holy A. (1998). Flow cytometry demonstrates bacteriocin-induced injury to Listeria monocytogenes. Current Microbiology 36(5): 266270.

Tanaka Y., Yamaguchi N. \& Nasu M. (2000). Viability of Escherichia coli O157:H7 in natural river water determined by the use of flow cytometry. Journal of Applied Microbiology 88: 228-236.

Tempelaars M.H., Rodrigues S. \& Abee, T. (2011). Comparative analysis of antimicrobial activities of valinomycin and cereulide, the Bacillus cereus emetic toxin. Applied and Environmental Microbiology. 77(8): 2755-2762.

Tortorello M.L. \& Stewart D.S. (1994). Antibody-Direct Epifluorescent Filter Technique for Rapid, Direct Enumeration of Escherichia coli 0157:H7 in Beef. Applied and Environmental Microbiology 60(10): 3553-3559.

Tyndall R.L., Hand Jr. R.E., Mann R.C:, Evans C. \& Jeringen R. (1985). Application of flow cytometry to detection and characterization of Legionella spp. Applied and Environmental Microbiology 49(4): 852-857.

Ueckert J.E., ter Steeg P.F. \& Coote, P.J. (1998). Synergistic antibacterial action of heat in combination with nisin and magainin II amide. Journal of Applied Microbiology 85(3): 487-494

Uyttendaele M., Rajkovic A., Van Houteghem N., Boon N., Thas O., Debevere J. \& Devlieghere F. (2008). Multi-method approach indicates no presence of sub-lethally injured Listeria monocytogenes cells after mild heat treatment. International Journal of Food Microbiology 123: 262-268.

Valdivia R.H. \& Falkow S. (1996). Bacterial genetics by flow cytometry; rapid isolation of Salmonella typhimurium acid-inducible promoters by differential fluorescence induction. Molecular Microbiology 22: 367-378.

Valdivia R.H. \& Falkow S. (1998). Flow cytometry and bacterial pathogenesis. Current Opinion in Microbiology 1: 359-363.

Valdivia R.H., Hromockyj A.E., Monack D., Ramakrishnan L. \& Falkow S. (1996). Application for green fluorescent protein (GFP) in the study of host-pathogen interactions. Gene 173: 47-52.

Veal D.A., Deere D., Ferrari B., Piper J. \& Attfield P.V. (2000). Fluorescence staining and flow cytometry for monitoring microbial cells. Journal of Immunological Methods 243: 191210.

Vermeulen A., Gysemans K.P.M., Bernaerts K., Geeraerd A.H., Van Impe J.F., Debevere J. \& Devlieghere F. (2007). Influence of $\mathrm{pH}$, water activity and acetic acid concentration on Listeria monocytogenes at $7^{\circ} \mathrm{C}$ : data collection for the development of a growth/no growth model. International Journal of Food Microbiology 114: 332-341.

Vives-Rego J., Lebaron P. \& Nebe-von-Caron G. (2000). Current and future applications of flow cytometry in aquatic microbiology. FEMS Microbiology Reviews 24(4): 429-448.

Walberg M., Gaustad P. \& Steen H.B., (1997). Rapid assessment of ceftazidime, ciprofloxacin and gentamicin susceptibility in exponentially-growing $E$. coli cells by means of flow cytometry. Cytometry 27: 169-178. 
Wang Y., Hammes F., De Roy K., Verstraete W. \& Boon N. (2010). Past, present and future applications of flow cytometry in aquatic microbiology. Trends in Biotechnology 28: 416-424.

Yamaguchi N. \& Nasu M. (1997). Flow cytometric analysis of bacterial respiratory and enzymatic activity in the natural aquatic environment. Journal of Applied Microbiology 83: 43-52.

Yamaguchi N., Sasada M., Yamanaka M. \& Nasu M. (2003). Rapid detection of respiring Escherichia coli O157:H7 in apple juice, milk and ground beef by flow cytometry. Cytometry part A 54A: 27-35.

Zuzarte M., Gonçalves M.J., Cavaleiro C., Canhoto J., Vale-Silva L., Silva M.J., Pinto E. \& Salgueiro L. (2011). Chemical composition and antifungal activity of the essential oils of Lavandula viridis L'Hér. Journal of Medical Microbiology 60: 612-618. 


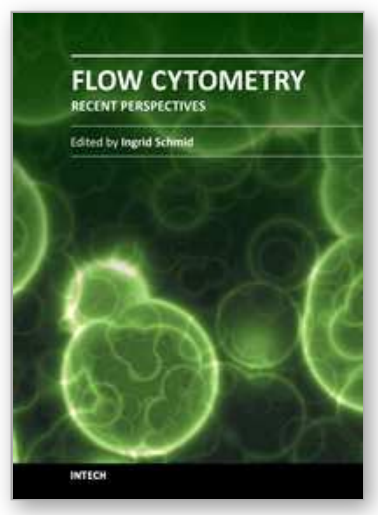

\section{Flow Cytometry - Recent Perspectives}

Edited by M.Sc. Ingrid Schmid

ISBN 978-953-51-0626-5

Hard cover, 500 pages

Publisher InTech

Published online 13, June, 2012

Published in print edition June, 2012

"Flow Cytometry - Recent Perspectives" is a compendium of comprehensive reviews and original scientific papers. The contents illustrate the constantly evolving application of flow cytometry to a multitude of scientific fields and technologies as well as its broad use as demonstrated by the international composition of the contributing author group. The book focuses on the utilization of the technology in basic sciences and covers such diverse areas as marine and plant biology, microbiology, immunology, and biotechnology. It is hoped that it will give novices a valuable introduction to the field, but will also provide experienced flow cytometrists with novel insights and a better understanding of the subject.

\section{How to reference}

In order to correctly reference this scholarly work, feel free to copy and paste the following:

Antonello Paparella, Annalisa Serio and Clemencia Chaves Lopez (2012). Flow Cytometry Applications in Food Safety Studies, Flow Cytometry - Recent Perspectives, M.Sc. Ingrid Schmid (Ed.), ISBN: 978-953-510626-5, InTech, Available from: http://www.intechopen.com/books/flow-cytometry-recent-perspectives/flowcytometry-applications-in-food-safety-studies

\section{INTECH}

open science | open minds

\section{InTech Europe}

University Campus STeP Ri Slavka Krautzeka 83/A 51000 Rijeka, Croatia Phone: +385 (51) 770447 Fax: +385 (51) 686166 www.intechopen.com

\section{InTech China}

Unit 405, Office Block, Hotel Equatorial Shanghai No.65, Yan An Road (West), Shanghai, 200040, China 中国上海市延安西路65号上海国际贵都大饭店办公楼405单元 Phone: +86-21-62489820

Fax: +86-21-62489821 
(C) 2012 The Author(s). Licensee IntechOpen. This is an open access article distributed under the terms of the Creative Commons Attribution 3.0 License, which permits unrestricted use, distribution, and reproduction in any medium, provided the original work is properly cited. 